\title{
TURISMO Y ESPACIO TURÍSTICO: UN ANÁLISIS TEÓRICO CONCEPTUAL DESDE LA CIENCIA GEOGRÁFICA
}

\author{
Carlos Andrés Pinassi* \\ Patricia Susana Ercolani **
}

\begin{abstract}
El objetivo general que guía esta investigación consiste en comprender las múltiples acepciones del turismo y las relaciones en torno al espacio turístico y su clasificación, desde una perspectiva geográfica. En este contexto, los constructos: turismo y espacio turístico adquieren gran protagonismo, transformándose dicha actividad de ocio en una consumidora y productora del espacio geográfico. No se pretende realizar un detalle pormenorizado de conceptos y caracterizaciones, sino indagar acerca de las principales relaciones que se producen entre ambos. La investigación constituye un ensayo de carácter teórico, con un alcance metodológico explicativo, en el que se exploran y discuten constructos estructurales vinculados a la temática en tratamiento. A modo de aporte, se presenta como propuesta una nueva clasificación del espacio turístico, a partir de autores clave referenciados.
\end{abstract}

Palabras Clave: Turismo. Espacio turístico. Atractivo. Producto turístico. Geografía.

\section{TOURISM AND TOURISTIC SPACE: A THEORETICAL CONCEPTUAL ANALYSIS FROM GEOGRAPHIC SCIENCE}

The general objective of this research is to understand the different meanings of tourism and the relations around the tourist space and its classification from a geographical perspective. In this context, the constructs: tourism and tourist space take on a major role, transforming this leisure activity into a consumer and producer of the geographical space. It is not intended to make a detailed detail of concepts and characterizations, but to inquire about the main relationships that occur between both. The research is an essay of a theoretical nature, with an explanatory methodological scope, in which structural constructs linked to the subject under treatment are explored and discussed. As a contribution, a new classification of the tourist space is proposed, based on referenced key authors.

Keywords: Tourism. Touristic space. Attractive. Touristic product. Geography.

\section{TURISMO E ESPAÇO TURÍSTICO: UM ANÁLISE TEÓRICO CONCEITUAL A PARTIR DA CIÊNCIA GEOGRÁFICA}

O objectivo global desta pesquisa é compreender os diferentes significados de turismo e relações em todo o espaço turístico e sua classificação de uma perspectiva geográfica. Neste contexto, constrói: turismo e espaço turístico adquirir grande destaque, transformando esta atividade de lazer em um consumidor e produtor do espaço geográfico. Não se pretende realizar uma análise detalhada dos conceitos e caracterizações, mas informar-se sobre as principais relações que ocorrem entre eles. A investigação é um teste teórico, com um âmbito metodológico explicativo, que são discutidas construções estruturais relacionadas com o problema de tratamento. Como contribuição, apresenta-se como proposto uma nova classificação do espaço turístico proposto, a partir de autores-chave referenciados.

Palavras Chave: Turismo. Espaço turístico. Atrativo. Produto turístico. Geografia.

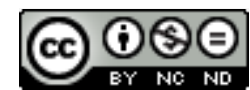

Licenciada por Creative Commons Atribuição Não Comercial / Sem Derivações/ 4.0 / Internacional

\footnotetext{
*Posdoctorando en Ciencias Humanas y Sociales (Facultad de Filosofía y Letras, Universidad de Buenos Aires/UBA Doctor en Geografía (2016) por la Universidad Nacional del Sur (UNS). Magíster en Gestión del Patrimonio Arquitectónico y Urbano, egresado de la Universidad Nacional de Mar del Plata. Licenciado en Turismo y Técnico Universitario en Emprendimientos Turísticos (UNS). Departamento de Geografía y Turismo, Universidad Nacional del Sur; Docente e investigador. Consejo Nacional de Investigaciones Científicas y Técnicas de la Rep. Argentina (CONICET); Becario Interno Posdoctoral. 12 de Octubre 1198, 4to. piso, Bahía Blanca (8000), Rep. Argentina. Áreas de interés: Turismo y patrimonio cultural. [ andres.pinassi@uns.edu.ar ]

** *Doctora en Geografía (2005) por la Universidad de las Islas Baleares (UIB) y la Universidad Nacional del Sur (UNS); Licenciada y Profesora en Geografía (UNS). Docente. -Investigadora del Departamento de Geografía y Turismo (UNS). Departamento de Geografía y Turismo, Universidad Nacional del Sur (UNS), Argentina. Calle 12 de Octubre 1198, 4to. piso, Bahía Blanca (8000), Rep. Argentina. Áreas de interés: Geografía del turismo. [ ercolani@uns.edu.ar ]
} 


\section{INTRODUCCIÓN}

Los antecedentes más remotos del turismo se pueden hallar en el "Grand Tour" (RAMOS, 2007; VERA et al., 2011; VELASCO, 2013), donde los jóvenes aristócratas europeos, realizaban sus largos viajes como parte de su formación profesional y personal.

Las bases del turismo actual, se enraízan en la Revolución Industrial (HIERNAUX, 2002; VERA et al., 2011), posibilitando un mayor ingreso económico en determinados sectores de la población y destinando gran parte de ello a la realización de viajes. Si bien, el consumo del ocio contemporáneo difiere mucho del de sus comienzos, se puede decir que los caracteres base que estructuran la práctica, se visualizan en dichas etapas históricas.

La evolución en la actividad, acompañada de ciertos desarrollos tecnológicos, económicos y sociales, ha demarcado un conjunto de acciones que se dan en torno al turismo, sumamente complejas de analizar, que requieren diferentes enfoques para su abordaje.

En este contexto, la investigación indaga a nivel teórico las acepciones del concepto de turismo, con un sesgo geográfico, y los componentes y relaciones que se producen en torno al espacio turístico, como lugar donde se desarrolla la actividad. En esta exploración conceptual, la visión de la geografía del turismo, como campo emergente de la ciencia geográfica (HIERNAUX, 2006), sustenta la postura conceptual adoptada, considerando que dicha disciplina aporta en la comprensión integral de la práctica y de los vínculos en torno a ella (COHEN; BENSENY, 2016).

Con relación a la metodología empleada, la investigación se caracteriza por albergar un alcance explicativo, en el que a partir de una exploración teórica se analiza al turismo y el espacio en el que tienen lugar sus prácticas. En este sentido, las publicaciones de índole académica, constituyen fuente de referencia específica, al igual que libros clave en la temática y actas de reuniones científicas.

El artículo se estructura en tres momentos: en primer lugar, se indaga acerca del concepto de turismo, teniendo como punto de partida las diferentes acepciones para referirse al mismo desde una perspectiva geográfica; en segunda instancia, se exploran los componentes y relaciones que se dan en torno al espacio turístico; por último, como aporte de la investigación, se presenta como propuesta una nueva clasificación del espacio del turismo, a partir de la realizada por diferentes autores de referencia específica en la temática.

\section{TURISMO: UNA MIRADA GEOGRÁFICA}

Definir al turismo, se torna una tarea sumamente compleja, debido a que existen disímiles conceptualizaciones, que lo caracterizan de acuerdo al objetivo que persiguen, no contando con una construcción uniforme y global que haya sido adoptada en forma genérica y que contemple los intereses de los diferentes actores partícipes de la actividad. Es así que se hace referencia al turismo como: industria, fenómeno, hecho, práctica/actividad, desplazamiento, sector/multisector, proceso y/o servicio/servicios (SANTANA, 1997). La diversidad de componentes y relaciones que son trasversales a la actividad turística, ha llevado a que este campo sea objeto de estudio de disímiles disciplinas, entre ellas la geografía. Barretto (2003, p.1) expresa: "En el área de la investigación sobre el turismo, rivalizan economistas, geógrafos, científicos sociales y turismólogos". Asimismo, se resalta la necesidad de llevar a cabo abordajes de dicha práctica social de manera multidisciplinaria, dado que el estudio desde una sola ciencia tendría una visión parcializada del fenómeno (BARRETO; OTAMENDI, 2010).

Como se planteara al comienzo, en este trabajo interesa analizar aquellas acepciones conceptuales que tienen cierta incidencia en el ámbito de la ciencia geográfica, es decir, las que presentan un estrecho vínculo con el espacio geográfico, dado que el mismo constituye el objeto de estudio de la geografía. Es así que se analiza en primera instancia la consideración del turismo como desplazamiento, para posteriormente tomar postura y hacer referencia al mismo como práctica o actividad socioeconómica. En ambos casos, la relación con el espacio es la variable clave. Sileo (2014, p.46) manifiesta al respecto: "Turismo y espacio están innegablemente desarrollados; de ahí el interés de la geografía en las problemáticas turísticas. Éstas precisan, para su comprensión, la mirada no sólo desde el punto de vista económico, sino también desde el punto de vista social y ambiental." Es desde las investigaciones en el campo de la geografía del turismo, que se contribuye a la comprensión de la práctica de ocio vinculada a implicancias políticas, económicas, ambientales, culturales, entre otras esferas, que se dan en un espacio dado (POCIDONIO; SILVA, 2014). Los citados autores expresan que el turismo importa a la ciencia geográfica a partir de dos ámbitos:

[...] un primero, que está relacionado con la necesidad de conocer las potencialidades de los lugares para la implantación de la actividad, procurando vincular las bondades que va a traer para el área en ese segmento de la economía; y un segundo, que se refiere a la 
búsqueda del entendimiento de la 'fragilidad' de los lugares para que éstos no sean afectados negativamente, 0 que, en reiteradas oportunidades se hayan generado cambios ambientales degradantes $\mathrm{y} / \mathrm{o}$ alteraciones culturales o pérdida de identidad cultural para las comunidades locales. (POCIDONIO; SILVA, 2014, p.35) $)^{1}$

En este último estadío, cabe plantear el análisis de los temas vinculados al patrimonio y el turismo, abordados tanto desde la ciencia geográfica, como desde otras disciplinas, dejando de lado la visión tradicional, centrada en su base etimológica, para posicionarse con un sentido más crítico, pensando no sólo al patrimonio como el mero legado de las sociedades pasadas, si no contemplando otras variables que llevan a considerarlo como una construcción sociocultural, creada por la sociedad o por sus representantes, en la que se traducen relaciones de poder. Este campo se complejiza aún más cuando el turismo hace uso 0 aprovechamiento de estos espacios históricos como atractivos de la actividad: ¿Qué problemáticas surgen? ¿Para quién se activa dicho patrimonio? ¿Para los visitantes? ¿Para los residentes? Diferentes investigaciones desde la ciencia geográfica han aportado en este sentido (BERTONCELLO, 2008; TRONCOSO, 2008, 2012; PINASSI, 2016).

A los enfoques propuestos por Pocidonio y Silva (2014), cabría añadir el vínculo turismo-espacioindividuos, dado a partir de la subjetividad y construcción de los seres sociales en torno a la práctica turística. La dimensión simbólica e inmaterial del espacio, se coloca como el tercer ámbito en el que el turismo se interrelaciona con la geografía. Un análisis desde esta perspectiva, en la que se analiza el vínculo entre el espacio vivido y la geografía del turismo, puede verse en Pinassi $(2015,2016)$. Cabe destacar, que sea cual fuere la relación turismociencia geográfica, el espacio (físico o simbólico) se configura como el nexo conector entre ambas disciplinas. La incursión del turismo como temática de investigación de la geografía se ha desarrollado desde el siglo XIX, a partir de estudios de carácter corológico, para adquirir a mediados del siglo XX una visión sistémica, sentando así las bases de una

\footnotetext{
${ }^{1}$ Cit. trad.: "[...] um primeiro, que está relacionado à necessidade de se conhecer as potencialidades dos lugares para a implantação dessa atividade, procurando vincular as benesses que venha a trazer para a área nesse segmento da economia; e um segundo, que se refere à busca do entendimento da "fragilidade" dos lugares para que estes não sejam afetados negativamente, o que, por muitas vezes, tem trazido alterações ambientais degradantes e/ou alterações culturais ou perda de identidade cultural para comunidades locais." (POCIDONIO; SILVA, 2014, p.35)
}

geografía del turismo ligada al análisis territorial de la actividad (MORERA; MIRANDA, 2015).

De acuerdo a lo establecido por Velasco (2013), existen tres grupos de conceptualizaciones del turismo: un primer grupo de definiciones que se generan a partir de disciplinas específicas, de acuerdo a fines e intereses del campo disciplinar. La autora destaca que estas conceptualizaciones resultan sesgadas por la demarcación propia del corpus teórico que estructura los diferentes campos del saber; una segunda esfera, que contempla constructos centrados en el turista como elemento clave de la práctica, demarcadas por un perfil netamente estadístico; y por último, un conjunto de conceptos desarrollados sobre la base de la noción de sistema, dado que contemplan una serie de componentes o elementos que determinan una visión integral de la actividad. A partir de los tres grupos particulares que destaca Velasco, se puede decir que la geografía como ciencia social, aporta una visión holística del turismo, dado que se apoya tanto en la primera como la tercera esfera, contribuyendo al entendimiento más allá del conjunto de saberes que estructuran la propia disciplina, sino yendo más allá e integrando a otras.

Desde la geografía tradicional del turismo, dicha práctica de ocio ha sido abordada como un desplazamiento, analizando los flujos entre los espacios emisores y receptores. En la actualidad, existen otros enfoques más analíticos que abordan al turismo desde una perspectiva holística e integral (HIERNAUX, 2002). Esta forma de abordaje se relaciona con la evolución epistemológica de la disciplina y de las ciencias sociales en general, arribando hoy día a una geografía del turismo ligada a lo cultural y cotidiano. Esto se vincula con el "giro cultural" producido en el seno de las disciplinas que tienen al hombre como centro de análisis (GIBSON, 2008; HALL, 2013; PINASSI; ERCOLANI, 2015; PINASSI; VAN HOOF; ERCOLANI, 2017).

Burkart y Medlik (1981) y Mathieson y Wall (1982), obras clave referenciadas por diferentes investigadores (CROSBY; MOREDA, 1996; SANTANA, 1997; SANCHO, 1998; MONTERRUBIO; COLÍN, 2009), parten de definir al turismo como los desplazamientos de personas a lugares diferentes al de su entorno cotidiano. Si bien incluyen otras variables, como la realización de actividades y los servicios consumidos, la premisa base surge de la movilidad física de los individuos.

Como mencionan Monterrubio y Colín (2009) dichas conceptualizaciones, a comparación de las de carácter técnico-estadístico, han reflejado la complejidad del turismo, sin embargo, las mismas 
resultan aún acotadas, dejando de lado aspectos centrales en la esfera de la actividad.

Dentro de la misma línea, Getino (1987, 2003), establece dos acepciones del turismo. En primera instancia, sostiene: "Turismo es, en consecuencia, un recurso social producido por el hombre a través del procesamiento racional y deliberado de otros recursos, como son los naturales y culturales, para su utilización durante el llamado tiempo libre"; seguidamente manifiesta:

La actividad turística se define, también, como el desplazamiento voluntario de un individuo o un grupo de individuos por espacios distintos de sus lugares habituales de residencia con fines recreativos, culturales o de descanso, y ajenos a todo propósito remunerativo o de trabajo profesional. (GETINO, 1987, p.37).

La segunda acepción es la que más relación guarda con la conceptualización analizada. Si bien se refiere al turismo como actividad, alude al mismo como un desplazamiento de carácter voluntario, adicionando determinados estímulos de viaje.

Urry (2004), haciendo referencia a los elementos comunes en las definiciones de turismo, destaca al desplazamiento como promotor de las relaciones turísticas que se producen en el seno de la actividad. Analizarlo desde esta perspectiva, lleva a explorar los flujos turísticos en diferentes escalas geográficas, determinando ciertos espacios emisores y receptores partícipes de la actividad.

Algunos estudios contemporáneos, incursionan en dicha variable y lo abordan como una "forma de movilidad", donde la misma se estudia y contempla dentro de la cotidianeidad, como una acción no diferenciada y similar al resto que realizan las personas (COOPER, 2007). En este contexto, Hall y Page (2014) y, en la misma línea de trabajo, Coles, Duval y Hall $(2005$, p.184) sostienen que "el turismo es, en esencia, una forma de movilidad temporal y por consiguiente es análogo tanto en su alcance como en su significado a otras formas de movimiento voluntario (por ejemplo, los viajes a segundas residencias, el retorno migratorio, la emigración)."

En la misma línea de tratamiento se destaca Russo (2016, p.18), quien expresa que el turismo se ha trasformado en una movilidad que forma parte del mundo cotidiano en el que trascurre la sociedad actual: "[...] si el estudio del turismo moderno trataba de lo excepcional y efímero en la vida de las personas, hoy en día el turismo -y la movilidad en general- se considera una dimensión fundamental de la cotidianidad". Es decir, que el turismo deja de ser considerado como algo extraordinario, que ocurre de manera esporádica y que tiene como motivación de viaje el ocio o las vacaciones, sino que se incorpora al espacio de vida de los sujetos, como una actividad más, entre tantas que realizan.

No queda duda que el turismo implica desplazamiento físico (de ida y retorno), pero no basta con analizarlo solamente desde dicha perspectiva. De acuerdo a lo establecido por Hiernaux (2006), a pesar de que esta variable resulta clave para que exista turismo, los geógrafos no han profundizado demasiado en este sentido.

La segunda acepción que interesa analizar, es la del turismo como práctica o actividad. En este contexto, se pueden distinguir dos tipos de abordaje a partir de las distintas definiciones planteadas y del objetivo y esfera desde la que se desarrolla: uno de forma técnica o asociada a fines estadísticos; y otro más bien analítico 0 teórico-conceptual. La diferenciación surge también en la consideración del tipo de actividad o práctica. Existen autores que lo conceptualizan como una práctica/actividad de carácter social, otros, de tipo económica, y en última instancia, los que lo denominan como la conjunción de ambas: socioeconómica (Figura 1).

Figura 1 - El turismo como práctica/actividad.

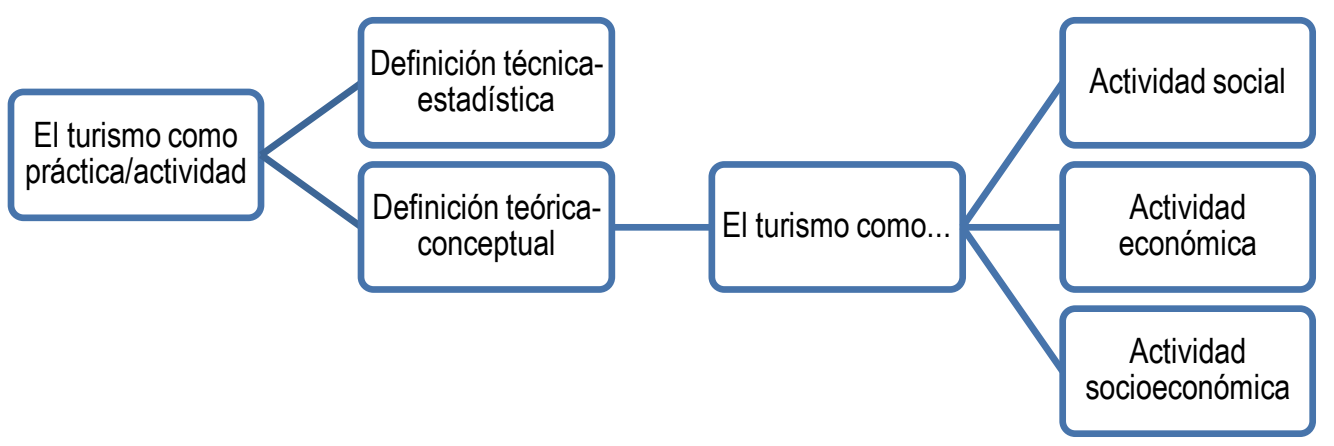

Fuente: elaboración propia. 
Más allá de analizar si dichas definiciones provienen 0 no de la ciencia geográfica, interesa profundizar en la consideración como actividad o práctica en sí misma, dado que la connotación de social o económica otorgada al turismo lo vincula con el espacio, como producto social.

Dentro de las conceptualizaciones de tipo técnica o estadística, la más difundida y aceptada, es la de la Organización Mundial del Turismo, quien establece: "El turismo comprende las actividades que realizan las personas durante sus viajes y estancias en lugares distintos al de su entorno habitual, por un período de tiempo consecutivo inferior a un año con fines de ocio, por negocios y otros" (ONU; OMT, 1994, p.5). Esta definición es completada en el año 2000 con las Recomendaciones de Estadísticas en Turismo (ONU; OMT, 2000, p.7), adicionando al final, que los "otros motivos" no se deben encontrar "[...] relacionados con el ejercicio de una actividad remunerada en el lugar visitado". Tal consideración, no da lugar a duda de que se trata de una conceptualización operativa con fines estadísticos. Las actividades, temporalidad, motivación, la diferenciación entre el lugar de residencia y el lugar visitado, dejan en claro la necesidad de "encasillar" y distinguir un visitante (turista 0 excursionista) de otro tipo de viajero.

El Tesauro Turístico Argentino, si bien no explicita de manera detallada determinados componentes como lo hace la definición citada anteriormente, denota un perfil simplista en la consideración de la práctica. Define al turismo, manifestando: "Es el complejo de actividades originadas por el desplazamiento temporal y voluntario de personas fuera de su lugar de residencia habitual, invirtiendo en sus gastos, recursos que no provienen del lugar visitado" (TORREJÓN, 2013, p.33). Dichas definiciones, resultan óptimas a los fines que persiguen: obtener datos estadísticos. Sin embargo, son acotadas a los fines teóricoconceptuales. Desde esta última perspectiva, existen autores que consideran al turismo como una práctica social (KNAFOU, 1996; BERTONCELLO, 2002; ALMIRÓN, 2004; BALASTRERI RODRIGUES, 2006; CAMMARATA, 2006; KUPER; BERTONCELLO, 2008; GARCÍA, 2013; COHEN; BENSENY, 2016), con una connotación geográfica distintiva en las denominaciones.

Bertoncello, realiza una crítica a la definición tradicional de la OMT, y determina una serie de factores que no son considerados en la conceptualización, ni en la mayoría de las existentes, dando apertura a nuevas variables que posibiliten obtener un panorama más integral y enmarcado en un contexto determinado, y no considerar al turismo como práctica aislada que se da en el territorio.
La definición [la de la OMT] refiere al turismo como una práctica social protagonizada por determinados sujetos sociales: los turistas; nada dice, en cambio, respecto a que también participan en ella otros sujetos, tales como agentes económicos, comunidad de origen y destino, y que cada uno forma parte de una determinada sociedad, en la cual ocupan roles específicos, actúan según intereses y desde lugares de poder diversos, etcétera. (BERTONCELLO, 2002, p.32)

Sobre la base del mismo razonamiento, Knafou y Stock (2003, p.931) manifiestan que "el turismo es un sistema de actores, de prácticas y de espacio que participan de la recreación de los individuos por el desplazamiento y el habitar temporal fuera de los lugares de lo cotidiano". Si bien los citados autores hablan de sistema, hacen referencia en este caso a la articulación entre los distintos componentes del proceso turístico, según manifiesta Hiernaux (2008). En este caso, la ampliación a otros elementos 0 unidades del territorio turístico (KNAFOU, 1996; BERTONCELLO, 2002), no encasillan a la práctica de ocio contemplando sólo al desplazamiento y lo acotado a ello, sino al conjunto de actores que se relacionan en los diferentes espacios que se articulan en dicha actividad. En esta línea, Russo expresa que es necesario entender al turismo como un sistema, constituido por múltiples elementos, en el que el turista juega un papel fundamental. Dicha práctica de ocio debe ser interpretada como

[...] un sistema ordenado y ordenador de materialidades, prácticas, relaciones y movilidades, y ya no solamente como 'sector económico'; y los turistas como parte de la población urbana 0 ciudadanos temporales, con una fuerte capacidad de actuación sobre la transformación y re-significación del espacio, y ya no como meros 'clientes'. (RUSSO, 2016, p.27)

En este sentido, el turismo es considerado como productor y consumidor del espacio, a partir de la socialidad y espacialidad de los visitantes en el destino. El turista adquiere un rol relevante en el espacio de vida del área receptora, trasformando los espacios en lugares turísticos, a partir de la apropiación que realice de éstos.

En la esfera de las ciencias económicas, se pueden mencionar los aportes de Figuerola (1985, p.15) quien, desde esta perspectiva, define al turismo como: "[...] un acto que supone desplazamiento, que conlleva gasto de renta, cuyo objetivo principal es conseguir satisfacción y servicios, que se ofrece a través de una actividad productiva, generada 
mediante una inversión previa". Asimismo, este autor manifiesta que de todas las acepciones del término turismo, la adoptada como más conveniente es la de actividad económica,

[...] puesto que esta expresión recoge casi por completo todos los elementos definitorios que hemos ido aportando hasta el momento, es decir: La recreación es una actividad que realizan los individuos, separados 0 colectivamente; Los desplazamientos son actos que suponen gasto de bienes; El consumo de la renta, igualmente, puede concebirse como una actividad más; Por último, la generación de riqueza a través del proceso productivo es una clara y tipificada actividad económica. (FIGUEROLA, 1985, p.17)

Si bien la definición planteada por este autor, tiene un sesgo económico bien marcado, se denota la apertura e inclusión de elementos comunes, descritos en algunas de las conceptualizaciones destacadas anteriormente. De este mismo modo, se destacan los aportes de diversos grupos de economistas que abordan al turismo desde esta perspectiva (BRIDA, PEREYRA, PULINA, SUCH, 2013; BRIDA, LANZILOTTA, PEREYRA, PIZZOLON, 2013; DE PAULA, 2016). En ese sentido, como parte de uno de los enfoques, el turismo es visualizado como la actividad económica, que utilizado como política de estado, propende al desarrollo de los territorios, en muchos casos con conflictos socio-espaciales aparejados, dado los impactos negativos que puede provocar. Los aportes de De Paula (2016) se presentan en este sentido.

Por toda América Latina, el turismo es el discurso evocado sobre el aprovechamiento de los beneficios de la actividad y su retorno a la población también ha sido el contexto por el cual se dieron grandes proyectos de transformaciones en los espacios, impactando en la distribución espacial, tocando necesariamente cuestiones del ámbito económico, urbanístico, ambientales y sociales. [...] el fomento de la actividad turística se vuelve un contexto agravante donde es posible observar el traspaso sobre demandas del orden público con intenciones de redistribuir, controlar y evitar los pobres, en el ámbito de la lucha por el control del espacio. (DE PAULA, 2016, p.23)²

\footnotetext{
2 Cit. trad.: "Por toda América Latina, o turismo é o discurso evocado sobre o aproveitar os benefícios da atividade e seu retorno para a população tem sido o contexto pelo qual grandes projetos de transformações nos espaços se dão, impactando a distribuição espacial, tocando necessariamente questões do âmbito econômico, urbanístico, ambientais e sociais. [...]
}

Si bien la citada autora hace referencia al caso específico de Brasil, gran parte de las implicancias negativas asociadas al turismo, se dan debido a que el mismo es reducido a una mera actividad económica y utilizado como instrumento discursivo en las políticas para el desarrollo territorial, bregando por objetivos financieros y no sociales. Considerar al turismo solamente como una actividad económica, deja de lado un cúmulo de cuestiones vinculadas a los sujetos como elementos dinámicos dentro de la esfera turística, siendo necesario ir más allá e incluir aspectos culturales y sociales, propios del hombre (MANTERO, 1997; PANOSSO, 2007). En este contexto, la articulación de ambas perspectivas, la económica y la social, posibilitan un abordaje más integral, relacionando factores de implicancia en ambos campos de actuación.

Asimismo, otros autores (HIERNAUX, 2002; VERA et al., 2011), sostienen que el turismo, más que actividad económica en sí misma, es un "inductor 0 generador" de otras de diversa índole, que repercuten con gran impacto en el desarrollo de los países.

A partir de lo expuesto, y de acuerdo a los fines de la investigación, interesa entonces plantear la acepción de lo que se considera turismo desde una perspectiva geográfica: el mismo es visualizado como una actividad socioeconómica, con gran implicancia espacial, que contempla e incluye a otras de diversa índole. Asimismo, es resultado de procesos sociales que posibilitan la consolidación y apertura de dicha práctica a determinados sectores de la población (HIERNAUX, 2002; GUIMARÃES, 2012).

El turismo considera en su seno, un desplazamiento físico, de ida y retorno, generado por un estímulo de viaje. Dicho cambio implica: otro marco geográfico, otras actividades, relaciones socioculturales disímiles, y un consumo y distribución del tiempo de los individuos totalmente diferente al que hacen en su entorno habitual. El viaje, lleva asociado una gran carga psicológica y emotiva, ya que implica la formación de imágenes en torno al destino, en las diferentes etapas de la movilidad y del cambio de entorno, lo que determina una actitud de los sujetos participantes de la actividad para con el lugar visitado. Como actividad compleja, intervienen diferentes actores sociales, públicos y privados, en los distintos espacios participantes, que se articulan en el sistema turístico, y que trabajan en pos del funcionamiento de la práctica. En este contexto, reaparecen conflictos vinculantes a la operatoria y

[...] o fomento da atividade turística se torna um contexto agravante onde é possível observar o transpasso sobre demandas da ordem pública com intento de realocar, controlar e evitar os pobres, no âmbito de luta pelo controle do espaço." (DE PAULA, 2016, p.23) 
gestión turística del destino. Cada componente no actúa en forma imparcial, sino con intereses y relaciones de poder propias, que condicionan su desarrollo en el espacio turístico.

La capacidad de síntesis de la ciencia geográfica aporta a la práctica una visión integral, que muchas otras disciplinas por sus objetos de estudio, llevan a una concepción parcializada del turismo. Desde esta ciencia, dicha actividad socioeconómica se visualiza como como una práctica productora y consumidora del espacio, es decir que el turismo se trasforma en promotor de procesos de creación y configuración espacial, que a su vez el mismo va a demandar. Como sostienen Hernández y Monterrubio (2016, p.37), "Ios espacios turístico-recreativos se construyen socialmente, y dichas construcciones se generan en función de los significados, las prácticas e interacciones de quienes los visitan, principalmente". En esta construcción social, el turismo trasforma estos espacios en lugares turísticos, a partir de la carga valorativa que le es otorgada durante las diferentes etapas del viaje.

En la actualidad, se están dando una serie de tendencias en las temáticas y formas de abordaje del turismo, que llevan a pensar y re-pensar nuevas perspectivas de incursionar la actividad desde la investigación. De acuerdo a lo expresado por Troncoso (2016), se ha despertado un interés por colocar al sujeto y la experiencia de viaje en el centro de la escena. "En esta línea de indagación se ha buscado comprender cómo el turista experimenta los viajes turísticos más allá de lo propuesto (a veces interpretado como impuesto) por la industria turística" (TRONCOSO, 2016, p.75). Asimismo, la citada autora expresa la recuperación de la línea de trabajo que se sustenta en el individuo y sus representaciones en torno al turismo. Estos abordajes, van de la mano del giro cultural en las ciencias sociales que, como parte de ello, ha dado marco a los nuevos enfoques en la ciencia geográfica, llevando a un cambio en la concepción espacial, en la que el espacio vivido, las representaciones, la concepción de lugar, entre otros conceptos clave en el campo de la geografía humanística, cobran relevancia. Guimarães (2012) presenta un interesante abordaje en este sentido. Desde la mirada de las Ciencias Sociales, incursiona en el análisis del concepto de "encuentros turísticos", en el que la subjetividad de los visitantes se coloca en el centro de la escena. Por otro lado, Troncoso (2016) visualiza a su vez en los estudios de género, en las relaciones de poder generadas en los destinos, y en el turismo como una forma de movilidad cotidiana, nuevos campos temáticos de estudio que hoy día cobran relevancia. En esta línea se expresa Russo (2016), quien hace referencia a tres giros (turn) en el ámbito de los estudios en turismo: el giro de las movilidades, el giro performativo y el giro creativo ${ }^{3}$. Si bien cada uno de estos cambios alberga caracteres independientes, de acuerdo a lo establecido por el citado autor, presentan puntos en común:

Se diferencian posiblemente (pero con muchos puntos de conexión) en el objeto y el objetivo de la mirada: los viajeros y los vehículos de la movilidad -en el caso del mobilities turn- que llega [...] a considerar las consecuencias culturales y económicas de la movilidad sobre las formas de funcionar de la sociedad; el cuerpo, sus expresiones y su interacción con el lugar -en el caso del performative turn- que se plantea sobre todo analizar y criticar las formas de expresión del poder; $y$, por último, la creación y el disfrute de la cultura -en el caso del creative turn- que asigna al turismo una función de enriquecimiento universal. (RUSSO, 2016, p.23)

En este último caso, en el marco del giro creativo, se pueden destacar los aportes recientes realizados por Tresserras (2014), vinculados al denominado "turismo naranja", como una modalidad de turismo cultural y creativo. Cabe pensar en el marco de estas perspectivas que llevan a una cotidianización del turismo: ¿Qué rol ocupa la ciencia geográfica? ¿Cuál es el aporte de los geógrafos del turismo a estas transiciones? ¿Cómo pensar formas de abordaje que articulen diferentes campos de la ciencia geográfica? ¿Cómo pensar una geografía del turismo nutrida desde las geografías de la vida cotidiana?

\section{ESPACIO TURÍSTICO: COMPONENTES Y RELACIONES}

El espacio geográfico, como objeto de estudio de la ciencia geográfica, es producto de la sociedad que lo habita. Lo adapta, organiza y modifica de acuerdo a sus parámetros culturales y formas de vida, adecuándolo para satisfacer sus diferentes necesidades. El espacio adaptado para satisfacer un estado de carencia o un deseo vinculado al ocio de los visitantes, es el denominado espacio turístico. El espacio geográfico devendrá con un carácter turístico, a partir de la presencia de recursos culturales y naturales y por la disposición de cierto equipamiento específico e instalaciones que demanden los visitantes. Es decir, que la funcionalidad turístico

${ }^{3}$ Mobilities turn, performative turn y creative turn (RUSSO, 2016). 
recreativa del mismo, otorga tal connotación al espacio geográfico.

Antón, Fernández y González (2007, p.132), sostienen:

Los espacios turísticos son lugares donde confluyen el desarrollo de productos destinados al ocio, la recreación y el tiempo libre para visitantes no permanentes con el consumo de dichos recursos -ya sean tangible $e$ intangibles- a través de la vivencia de experiencias que generan satisfacción. De la combinación entre la organización de los componentes del espacio (lugar, recursos, productos y agentes) y la gestión del espacio turístico surge una mayor o menor calidad de la experiencia turística, que es percibida y traducida simbólicamente por el turista.

De lo expuesto, se deduce que la determinación de un espacio como turístico, se encuentra dada por la presencia de ciertos recursos territoriales, que se constituyen efectiva o potencialmente como atractivos. Su presencia, adicionada a la existencia de servicios, equipamientos e instalaciones (planta turística), y la infraestructura que los complementa, conforman un espacio turístico como tal (BOULLÓN, 2006a, 2006b; ERCOLANI; BENSENY, 2010; VERA et al., 2011; SILEO, 2014). Asimismo, además de los aspectos materiales que definen y distinguen a un espacio como turístico de otro que no lo es, surgen los atributos inmateriales, vinculados al simbolismo, experiencia, imagen inducida y percibida, que lleva aparejado dicho lugar (CALLIZO, 1989; ANTÓN et al., 2007).

Más allá de su definición a partir de los elementos constitutivos del espacio del turismo, se puede manifestar aquella centrada en la propia atractividad del lugar. En este contexto, el mismo se conceptualiza "como aquel que es capaz de atraer, de modo más o menos constante, corrientes turísticas, a la vez que su economía refleja ingresos considerables por estas corrientes y su entorno se adecúa a las necesidades básicas de los turistas" (VERA et al., 2011, p.107). De tal connotación, se desprenden dos vertientes de análisis:

- Por un lado, quedan relegados los espacios en los que no se realiza la práctica de ocio con intensidad, pero que albergan cierta potencialidad turística de desarrollo. Es desde esta perspectiva, que los autores manifiestan: "[...] Su potencialidad no es suficiente para definir un espacio como turístico. Para ello, debe hacerse efectivo su funcionamiento" (VERA et al., 2011, p.193). En esta línea se coloca Sancho (1998) quien manifiesta que el espacio turístico se conforma no sólo por la oferta turística, sino también por la demanda de visitantes que arriban a él.

- Desde la segunda perspectiva, la relativa a la atractividad, tal definición queda vagamente sustentada, ya que atribuye exclusivamente la generación de la atracción al espacio receptor, portador de los recursos. En este contexto, las posturas teóricas que otorgan la construcción de dicha atractividad a las sociedades de origen (BERTONCELLO, 2002; URRY, 2004; ALMIRÓN; BERTONCELLO; TRONCOSO, 2006), quedan relegadas. En este sentido ¿Qué sucede con los sitios que albergan potencialidad turística, pero que sus flujos de visitantes no son suficientemente relevantes? ¿Qué rol cumplen los potenciales turistas en los espacios emisores? ¿Son actores pasivos en dicha práctica de ocio?

Otra de las definiciones existentes, no coincidentes en este caso con la postura adoptada en esta investigación, es la establecida por Acebo y Schlüter (2012, p.165), quienes sostienen que "el espacio turístico se compone de tres elementos: a) espacio emisor, b) espacio receptor y c) espacio de tránsito". En este caso, puede decirse que más que espacio, la articulación de los tres componentes que mencionan estos autores, definen desde una perspectiva geográfica, un sistema turístico (Leiper, 1979), en el que se integran e interrelacionan disímiles espacios a partir de una misma actividad. Asimismo, la articulación de los elementos, se corresponde más con el concepto de territorio turístico establecido por Bertoncello (2002), que con el de espacio turístico.

De acuerdo a lo manifestado por Vera et al. (2011), la localización de la actividad turística y la propia configuración de los espacios turísticos, se determinan a partir de tres factores esenciales: factores ambientales, factores espaciales y factores socioeconómicos y políticos (Figura 2). Entre los primeros, los ambientales, se destacan los recursos territoriales, es decir, aquellos atributos que alberga el destino, que satisfacen una necesidad de ocio y que determinan la movilidad hacia el mismo. Con relación a los recursos geonaturales y geoculturales de localización, además de constituirse algunos en atractivos de uso turístico recreativo, condicionan 0 determinan el emplazamiento del asentamiento en el espacio geográfico. Entre los primeros se destacan, el clima, la vegetación, el relieve, entre otros; mientras que entre los segundos, las características culturales propias de la sociedad local que condicionan la forma 
de la trama urbana, la utilización de ciertos recursos culturales, entre otras variables.

Entre los factores espaciales, se pueden mencionar: la distancia entre el espacio emisor y receptor, en términos físicos, económicos (coste) y temporal; la distancia cultural, relativa a parámetros que estructuran la cultura local que pueden incidir en la realización del viaje al destino; la evolución en el transporte, que determina nuevas formas de acceso al espacio turístico; la localización relativa del mismo, respecto a importantes mercados emisores, a atractivos de gran relevancia, a vías de transporte clave, etc.; y la escala geográfica en la que se produce el desarrollo turístico, teniendo como marco la capitalización de los beneficios producidos por la actividad.

En la misma línea, los citados autores, establecen la existencia de factores económicos y políticos. En este caso, los mismos se determinan como aquellas variables del contexto, que condicionan el funcionamiento del sistema turístico. Entre ellas, se pueden mencionar a las variables económicas, sociales, tecnológicas, naturales, entre otras.

Figura 2 - Factores de configuración del espacio turístico.

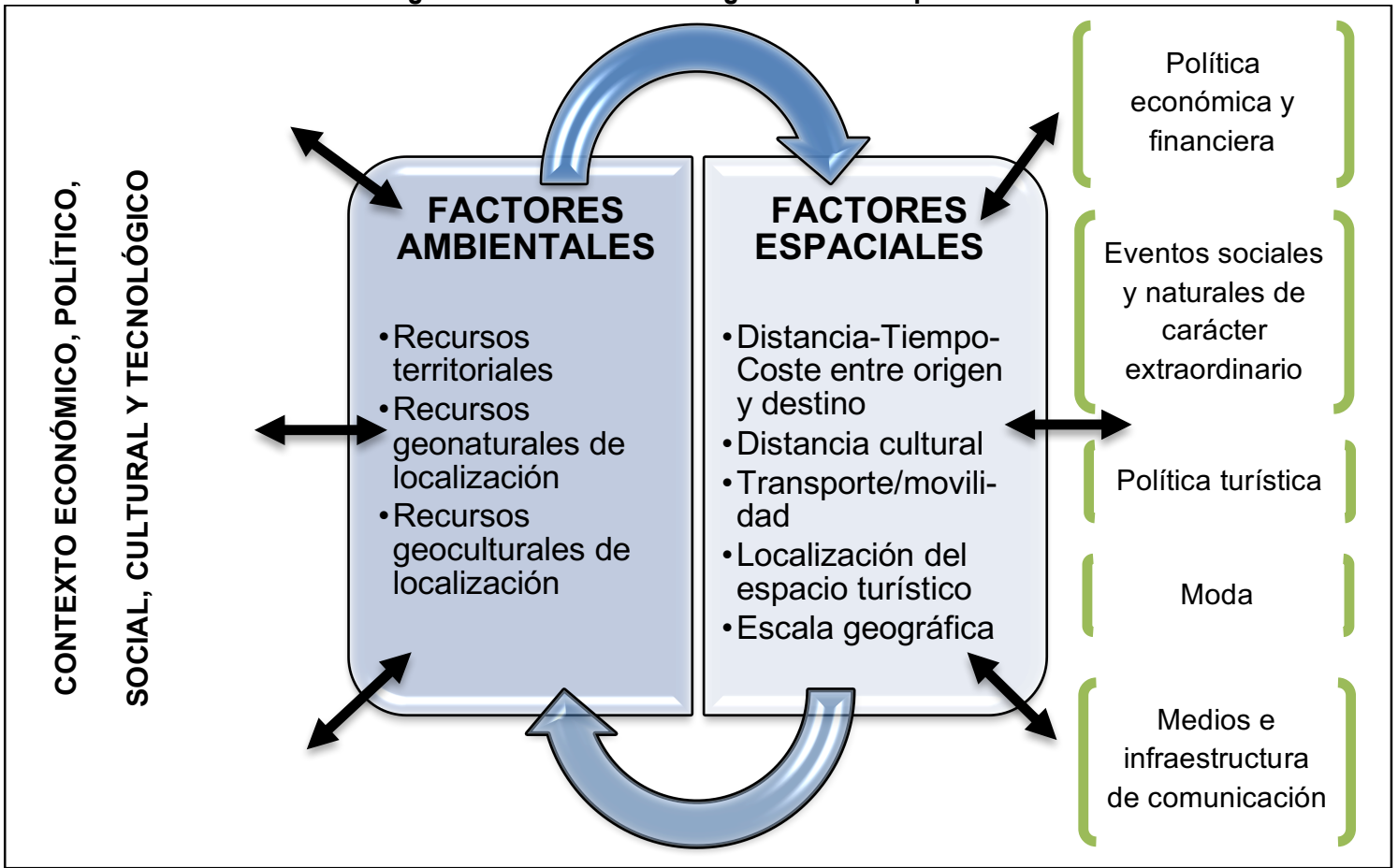

Fuente: elaboración propia a partir de Vera et al. (2011).

Como se mencionara con anterioridad, los recursos turísticos de un determinado lugar constituyen uno de los elementos base sobre los que se estructura el espacio turístico. En este contexto, debe precisarse qué se entiende por recurso, cuál es su diferencia con los atractivos, cómo los mismos devienen en productos, entre otras variables que resultan necesarias para comprender la dinámica del espacio en cuestión.

Sunyer, Galacho, García y López (2005, p.62), consideran como atractivo o recurso turístico a "todo elemento material que tiene capacidad, por sí mismo o en combinación con otros, de atraer visitantes a un determinado espacio, y cuando esa visita responde a motivos de turismo, ocio y recreación". Es decir, siguiendo la lectura que realizan los autores, "los recursos territoriales constituyen la materia prima de la actividad turística." En este sentido, los atributos naturales y culturales de un determinado espacio, se transforman en los recursos, susceptibles de uso y aprovechamiento por parte de los visitantes.

Por otro lado, Sancho (1998, p.183-184), manifiesta que el patrimonio turístico (entendido en este caso como recurso) "es el conjunto potencial (conocido o desconocido) de los bienes materiales 0 inmateriales a disposición del hombre y que pueden utilizarse, mediante un proceso de transformación, para satisfacer sus necesidades turísticas". En esta transformación, de recurso a atractivo y posterior conformación de un producto turístico, intervienen los diferentes procesos de patrimonialización 0 de asignación inducida de valor, considerando además, aquellos posteriores de gestión de atractivos y comercialización de productos. 
En este sentido, existe entonces un elemento cultural o natural que es valorado como tal por sus condiciones. Esta apreciación, manifestada por procesos de valorización, conlleva a su conversión en recurso. Dicha iniciativa de asignación de valor, puede ser llevada a cabo por el Estado, por actores locales (vecinos, instituciones, gestores), o por la valorización propia de los visitantes, contribuyendo a su activación y a su posterior conversión en atractivo. Es decir, como primera aproximación de análisis, sesgada en el espacio receptor, se puede manifestar que aquel recurso que es valorado por los visitantes y que genera un desplazamiento hacia el destino donde se localiza, se transforma en recurso turístico o atractivo en sí mismo (PINASSI; ERCOLANI, 2012) (Figura 3).

Figura 3 - Conversión de elemento cultural/natural a atractivo turístico.

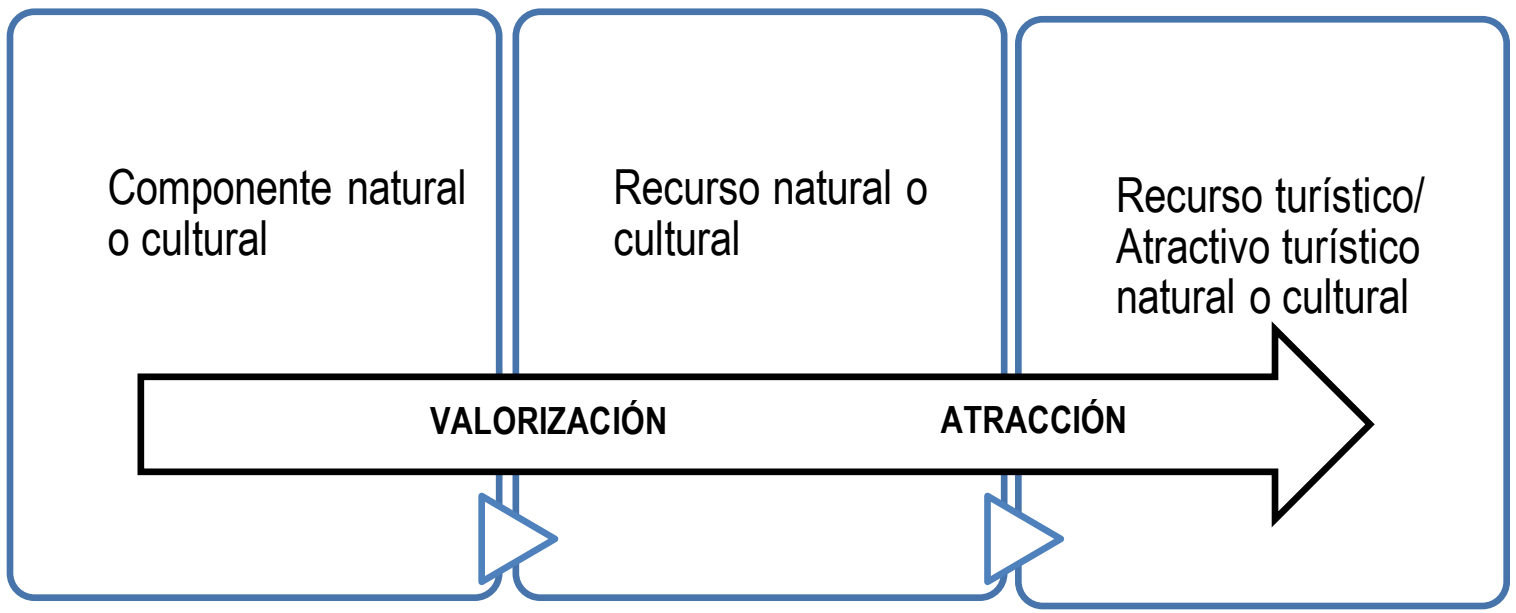

Fuente: elaboración propia a partir de Pinassi y Ercolani (2012).

En este proceso de conversión, se deben tener en cuenta los atributos propios y valores inducidos de los componentes culturales y naturales, evitándose que se activen bienes 0 gestionen atractivos, a partir de beneficios netamente económicos, en los que se conlleve a una espectacularización de la realidad (PRATS, 1997, 1998) o a una mercantilización extrema (TOSELLI, 2006), desvirtuando y afectando a la propia autenticidad del patrimonio territorial. Desde esta perspectiva, aparece en la ciencia geográfica una línea de investigación, que desde una mirada crítica, analiza los procesos de construcción patrimonial poniendo énfasis en la crítica al concepto tradicional de patrimonio, considerado como mero legado o herencia de un pasado. Dicha noción, como manifiestan diferentes autores (BERTONCELLO, 2008, 2010; GUZMÁN; GARCÍA, 2010; TRONCOSO, 2012) ha sido fuertemente cuestionada, ya sea por el destacado énfasis que pone en la dimensión temporal del pasado, por el carácter colectivo del patrimonio 0 por la connotación inmaculada que adquieren los bienes (PINASSI, 2016, 2017), los que son definidos y gestionados desde un presente, con un fin y discurso asociado, por un determinado poder imperante (económico, político). Entonces desde este presente, en quién se piensa para revitalizar dichos espacios históricos, ¿En los visitantes? ¿En los residentes? Una mirada integral sobre esta esfera, se presenta en la obra de Pinassi (2016), quien establece que el patrimonio debe pensarse en primera instancia para los pobladores locales y, a su vez, dichos sitios acondicionados para cumplir con una funcionalidad determinada, puedan ser utilizados por los propios turistas que arriben a la localidad.

Lo expuesto hasta aquí se ha analizado desde una sola mirada, la que converge en el propio espacio turístico. Esto permite deducir que el conjunto de recursos turísticos de un destino, constituyen aquellos componentes básicos o complementarios, pero no únicos, capaces de motivar a los individuos y generar un flujo de visitantes desde un área emisora, considerada ésta como el entorno habitual de dichas personas, hacia un espacio receptor, donde se encuentran los mencionados recursos territoriales. Bajo esta adjetivación, Tavares, Neves y Viera (2010, p.1074), establecen que "los factores de atractividad de un destino turístico son sus recursos naturales, deportivos y culturales, religiosidad, eventos, características del clima y gastronomía, entre otros". Los citados autores consideran a los atractivos naturales y culturales, adicionados a los acontecimientos programados, como el conjunto de 
bienes y manifestaciones captadoras de la atención de los visitantes e influyentes en la toma de decisión del viaje.

El análisis y la definición de la atractividad realizado hasta el momento, se ha establecido únicamente desde el enfoque de la oferta, fundamentándose en la definición de los caracteres propios del espacio turístico, como factores causantes del desplazamiento. Cabe plantear, que dicho concepto debe abordarse desde una perspectiva no sólo centrada en el área receptora, portadora de recursos y productos turísticos, sino en la mirada del visitante, quien desarrolla su residencia en un área emisora, distante al destino y quien define la atractividad propia de los recursos y del espacio turístico en su conjunto. Almirón et al. (2006), a partir de la lectura que realizan de Urry (1996), sostienen que la atractividad turística de un lugar no sólo debe analizarse desde el espacio receptor, sino desde las áreas emisoras, concentradoras de los potenciales turistas.

En este sentido, puede definirse entonces, desde dos perspectivas: en primera instancia, a partir de los recursos turísticos 0 atractivos, entendidos como un conjunto de componentes naturales 0 culturales, con ciertos atributos particulares en un determinado sitio, que existen previamente a la valorización que los visitantes hagan de dicho espacio; y por otro lado, establecen que la atractividad es una construcción social, que va más allá de la mera existencia de atributos en el territorio, sino que la misma se forma a partir de la combinación de estos últimos con ciertas cuestiones ajenas al espacio soporte de los atractivos. Dichas variables resultan relativas a los propios visitantes y al contexto en el que ellos están inmersos, como pueden ser las modas, gustos, hábitos de consumo, etc.

A partir de esta última postura, se atribuye la construcción de la atractividad a las sociedades de origen, es decir, la determinación de una actitud generadora del desplazamiento, propia de un espacio diferente al receptor, en el que se encuentran los recursos. En este caso, se imputa dicho proceso social al interés o mirada del turista sobre un espacio dado, como destaca Urry (2004, p.2):

No hay una mirada del turista como tal. Ella varía según la sociedad, el grupo social y el período histórico. Dichas miradas se construyen a través de la diferencia. [...] Lo que conforma una mirada particular del turista depende de aquello con lo cual se le contrasta, $y$ de cuales resulten ser las formas de actividad no turística. Por lo tanto, la mirada presupone un sistema de actividades y signos sociales que identifican prácticas turísticas particulares, no en términos de características intrínsecas, sino a través de contrastes implicados por las prácticas sociales no turísticas, en particular asociadas con el hogar y el trabajo asalariado.

Sostiene que esta mirada del turista puede ser inconstante o cambiable, examinando y persiguiendo nuevas alternativas, frente a lo ya conocido (URRY, 2004). Posicionar la construcción de la atractividad en la sociedad de origen, genera ciertos interrogantes, ya que considera la idea de que un lugar sólo podrá ser contemplado como turístico, si realmente interesa a los potenciales visitantes, que residen en un espacio diferente al que se localizan los atractivos. Queda así marginada, toda posibilidad de desarrollo de un determinado lugar, que potencialmente puede albergar atributos aprovechables por el turismo. Al respecto, Bertoncello (2002, p.42-43) manifiesta:

[...] con esto se están cuestionando fuertemente los estudios y prácticas orientados a la búsqueda 0 detección de atractivos potenciales como meros atributos del lugar: dicho en otros términos, podría decirse que no importa cuán importante, destacado, etc., es un rasgo (natural, histórico, cultural o lo que sea) del lugar de destino, sólo se valorizará como atractivo si logra coincidir con demandas existentes en la sociedad de origen de los turistas.

En el proceso de conversión de bienes culturales como atractivos turísticos, será necesario entonces compatibilizar ambas miradas, por un lado, analizar y exaltar los atributos particulares de los recursos turísticos, y por otro, tratar de definir las propuestas de gestión a partir de los intereses de los visitantes. Aquí entra en juego el papel que desempeña el marketing turístico, en tratar de identificar las necesidades y deseos de los turistas para, a partir de ello, diseñar productos concretos que respondan a sus exigencias. En este contexto, Bertoncello $(2008$, p.9) manifiesta:

Que los intereses de los potenciales turistas, junto con las condiciones objetivas del lugar, definen un campo de posibilidades de actuación social, que se concreta en distintos lugares. [...] intereses económicos y políticos, intereses grupales y concepciones de mundo, se articulan en acciones concretas que desembocan en las formas específicas que adquiere el proceso de definición de atractivos en cada lugar y en la elección de los lugares.

Siguiendo la misma línea de pensamiento, puede manifestarse que existen diferentes componentes del patrimonio territorial, con ciertas 
características que los hacen ser más o menos propensos a convertirse en verdaderos atractivos turísticos. Dependiendo de los valores que el componente natural o cultural albergue, en cuanto a parámetros estéticos, paisajísticos, históricos, entre otros, será más o menos apto para captar el interés de los potenciales visitantes de un destino turístico. A esto se le debe adicionar la posible declaratoria que posea el bien, otorgando la misma una valoración mayor, cuanto más elevado sea el estatus alcanzado.

En este sentido, se entiende que un lugar declarado Patrimonio de la Humanidad, representará una mayor apreciación, en términos de atractividad, que otro con declaratoria a nivel Provincial o Municipal (BERTONCELLO, 2008). Esta asignación de valor juega un rol fundamental en estos procesos, donde pueden ser las detonantes del desarrollo de la práctica turística en un determinado lugar, asociando a ello: formas de consumo, de planificación, ciertos impactos positivos 0 negativos, entre otras repercusiones que se puedan producir en el espacio de la actividad turístico recreativa.

Hasta aquí se ha hecho referencia únicamente a la existencia de los atractivos, como componentes clave a la hora de estructurar y configurar un espacio turístico con determinada atractividad. Sin embargo, por sí solos, más allá de que despierten el interés de viajar, los mismos se deben articular en un complejo entramado de elementos y relaciones que va más allá de su mera existencia. Dicho recurso debe ser "acondicionado" para la visita, es decir, que se debe gestionar una accesibilidad física, temporal y de mercado a dicho recurso. Para ello, se necesita de un conglomerado de elementos que posibiliten tal estructuración. En este proceso, se refleja el concepto de producto turístico. Al respecto Antón et al. (2007, p.105), manifiestan:

[...] los recursos son los elementos desencadenantes del proceso turístico. Pueden ser tangibles 0 intangibles, y se presentan en estado natural pero son tratados y agrupados al servicio de la satisfacción turística de sus usuarios potenciales, es decir, requieren un cierto grado de desarrollo para convertirse en atractivos turísticos y ser comercializados como auténticos productos turísticos. [...] La conversión de un recurso 0 atractivo en producto implica la selección de los mismos, su puesta en valor y requiere añadir elementos que posibiliten la formación de experiencias turísticas concretas a partir de sus contenidos.

Valls (1996, p.196), define al producto turístico como:

[...] un conglomerado, una amalgama, una constelación de elementos tangibles e intangibles en particular. Entre los elementos tangibles se hallan los bienes, los recursos, la infraestructura y los equipamientos; entre los intangibles se encuentran los servicios, la gestión, la imagen de marca y el precio.

Es decir, que los atractivos adquieren la caracterización de ser un elemento integrante más, entre varios, los que constituyen en su conjunto un producto turístico de un destino.

Por su parte Salinas y Medina (2009, p.228), adicionan determinadas características al concepto, vinculadas a la temporalidad, a las motivaciones, experiencias y a la forma en que el producto se materializa, a través de una actividad o servicio.

Los productos turísticos son ofertas de diferentes tipos que se preparan para ser brindadas al turista en forma de actividades y servicios, mediante el empleo de diferentes tecnologías $y / 0$ instalaciones. Deben ser capaces de motivar visitas a un lugar tanto por un corto tiempo hasta de varios días, para satisfacer un interés o necesidad específica de determinados servicios: recreativos, naturales, culturales, de salud u otros, o una combinación de varios de ellos, y que, además, propicien las mejores experiencias.

El patrimonio de una sociedad se transforma en su recurso principal, configurando mediante la articulación con el resto de los elementos, un producto turístico cultural o natural. En este contexto, Moreno (2001 citado en GUZMÁN; GARCÍA, 2010, p.39) en relación específica al patrimonio cultural, entiende por producto turístico cultural al:

conjunto de componentes tangibles e intangibles basados en los recursos patrimoniales culturales, los cuales resultan accesibles a los viajeros visitantes a través de la armonización de la gestión cultural y turística, siendo generadores de beneficios en forma de experiencias con sentido para un público específico, de manera tal que se garantice la sostenibilidad económica y ambiental de los factores que intervienen en su presentación.

Tal definición no sólo aplica a una tipología patrimonial específica, sino que la misma es extensiva al conglomerado de componentes antrópicos y biológicos que constituyen un territorio. Por otra parte, Tresserras (2006), realiza un aporte, estableciendo una serie de características formales, alusivas al proceso de transformación 0 conversión del patrimonio como recurso a producto turístico. Destaca que un producto debe ser: sostenible, atractivo, rentable, participativo (en su desarrollo y 
comercialización) y formativo, vinculado este último con la capacitación y educación de los prestatarios de los servicios turísticos y la propia población local, en el trato para con los visitantes (Figura 4). Bajo esta adjetivación, se contribuye al desarrollo de un producto turístico territorial y, por ende, de un espacio turístico, afianzado en preceptos arraigados en la propia sociedad o naturaleza, donde los atractivos integrantes sean identificados y seleccionados en base a criterios objetivos de determinación de valores y atributos albergados $\mathrm{y}$, a su vez, gestionados a partir de los intereses de los potenciales usuarios en cuestión.

Figura 4 - Configuración del producto turístico.

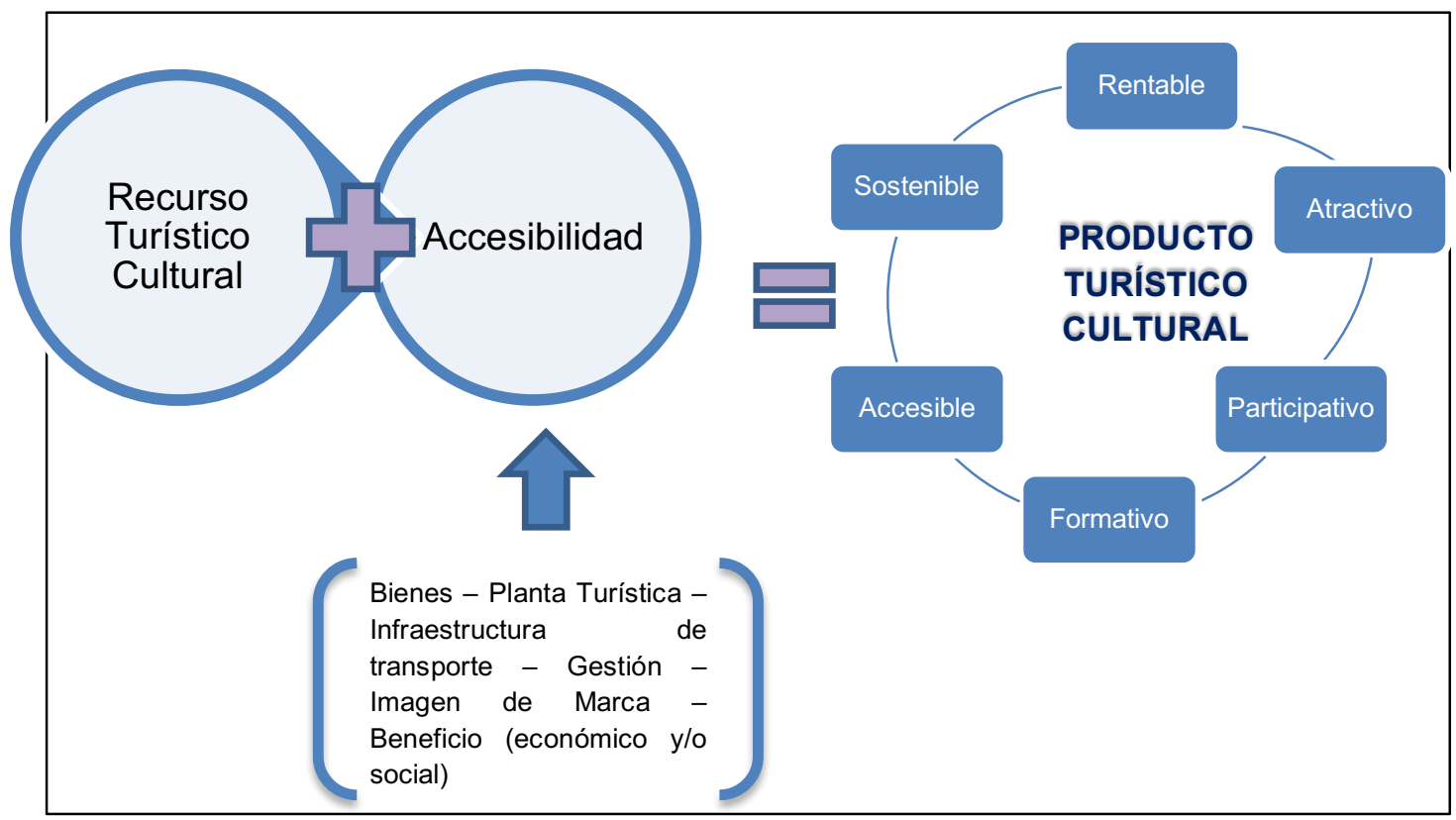

Fuente: elaboración propia a partir de Valls (1996); Tresserras (2006) y Pinassi (2016).

Considerar al producto turístico como una articulación entre componentes objetivos (tangibles) y subjetivos (intangibles), implica asumir que el propio espacio turístico que sirve de base a la estructuración de disímiles productos, también parte no sólo de una objetividad, sino también de una serie de imágenes y representaciones que se generan en torno a éste, lo que también influirá en la configuración de los productos que ese destino ofrezca. En este contexto, Da Soller y Castrogiovanni (2014, p.203) expresan: "[...] el espacio turístico es el sitio de encuentro de sujetos, éstos entre sí [los turistas] y éstos con la comunidad local y su patrimonio" (DA SOLLER, CASTROGIOVANNI, 2014, p.203) ${ }^{4}$. Estos procesos de socialidad y espacialidad en el destino turístico, conllevan a que dichos espacios sean vividos e interpretados a partir de la experiencia de viaje, trasformando estos espacios turísticos en lugares propiamente dichos. Los citados autores hacen referencia a la existencia de "entre-lugares turísticos", constituyendo una categoría conceptual que no llega a contemplar la totalidad de la complejidad del

\footnotetext{
${ }^{4}$ Cit. trad.: "[...] o espaço turístico é o local de encontros de sujeitos, desses entre si e desses com a comunidade local e seu patrimônio." (DA SOLLER, CASTROGIOVANNI, 2014, p.203)
}

constructo lugar, sino que solamente queda restringida a las imágenes del destino.

El entre-lugar es el espacio donde, la relación con el otro, el lugar del otro es asimilado y negociado al mío, sin que haya la efectivización del arraigo y de la objetivación de ese lugar, quedando restringido a las representaciones e imaginarios colectivos.

El espacio turístico parece ser tejido por los movimientos momentáneos de sujetos imbuidos en representaciones sociales, que movilizan interrelaciones plurales, produciendo los (entre) lugares en el sitio visitado. En este contexto, los sujetos turistas potencializan comportamientos entre sí y en los otros, que son tanto posibilitadores de la (entre) lugarización del turista, a partir del espacio vivido y aprehendido, cuanto de cierta extrañeza (positiva o negativa) del nativo para su propio lugar, que recurrentemente coloca en jaque su identidad y sus patrimonios (DA SOLLER, CASTROGIOVANNI, 2014, p.208209) 5 .

\footnotetext{
${ }^{5}$ Cit. trad.: "O entre-lugar é o espaço onde, na relação com o outro, o lugar do outro é negociado e assimilado ao meu, sem que haja a efetivação da ancoragem e da objetivação desse
} 
En ese sentido, el giro espacial en la geografía se extiende al propio objeto de estudio de la ciencia geográfica: el espacio turístico, considerando al mismo tiempo a éste como un complejo de relaciones que se producen entre componentes materiales e inmateriales. Se pueden manifestar aquí los nuevos aportes en la geografía del turismo que destaca Almirón (2004), quien resalta las contribuciones de Soja (1996), en la definición del concepto de "Tercerespacio" (Thirdspace). En el mismo "la especificidad espacial del urbanismo es investigada como un espacio enteramente vivido, un lugar simultáneamente real e imaginario, actual y virtual, lugar de experiencia y agencia estructuradas, individuales y colectivas" (Soja, 2008, p.40). Este tercerespacio, tiene su anclaje en las ideas de Lefebvre (1974 [2013]), quien distingue tres dimensiones o configuraciones del espacio en relación dialéctica: un espacio físico, concebido y vivido. A partir de lo expuesto, analizar al turismo y la recreación desde esta perspectiva geográfica, implica estudiar a los turistas/recreacionistas y su vinculación socio-espacial, en una triple esfera: la primera, enmarcada en las prácticas de ocio que realizan y su comportamiento en una dimensión espacio-temporal dada; en segundo lugar, la concepción y aprehensión de la realidad de la cual son partícipes; y, por último, determinar los espacios simbólicos que ellos construyen a partir de dicha actividad. Desde la visión de la sociedad como consumidora y productora del espacio, "[...] el turismo sería una práctica social [...] que precisa del espacio material, conceptual y vivido, y produce [a su vez] espacio, tanto material, conceptual como vivido" (ALMIRÓN, 2004, p.176).

\section{HACIA UNA CLASIFICACIÓN DEL ESPACIO TURÍSTICO}

De acuerdo al espacio geográfico sobre el que se desarrolla el destino, en base a sus recursos territoriales propios, los productos turísticos y recreativos gestionados y su funcionamiento

\footnotetext{
lugar, e assim ficamos restritos a suas representações e aos imaginários coletivos.

O espaço turístico parece ser tecido pelos movimentos momentáneos de sujeitos imbuídos de representações sociais, que mobilizam interrelações plurais, produzindo os (entre) lugares no local visitado. Nesse contexto, os sujeitos turistas potencializam comportamentos em si e nos outros, que são tanto possibilitadores da (entre) lugarização do turista, a partir do espaço vivido e apreendido, quanto de certa estranheza (positiva e negativa) do nativo para seu próprio lugar, que recorrentemente coloca em xeque sua identidade e seus patrimonios." (DA SOLLER, CASTROGIOVANNI, 2014, p.208209)
}

cotidiano, el espacio turístico puede clasificarse de diversas formas. Distintos autores incursionan en diferentes tipologías espaciales a partir de los objetivos de sus investigaciones. De acuerdo a lo planteado por Vera et al. (2011), el desarrollo de tipologías del espacio turístico por parte de la geografía del turismo se encuentra en una fase inicial, debido al gran dinamismo de la actividad y a la diversidad de elementos y relaciones que se dan en torno a la práctica. Los citados autores expresan la necesidad de contar con una categorización universal que permita agrupar criterios, sin el perjuicio que esto lleve a la exclusión de ciertas locaciones turísticas por no compartir los atributos de estas catalogaciones.

En este contexto, se analizan cuatro autores clave en la esfera geográfica (Tabla 1), para posteriormente sentar las bases de una propuesta de clasificación, que pueda ir profundizándose a futuro a partir de nuevas investigaciones y abordajes teóricos sobre la disciplina. El objetivo en este caso no es desarrollar de manera exhaustiva tal clasificación, sino establecer los lineamientos básicos que definan una tipología genérica del espacio turístico.

En el caso de Lozato-Giotart (1990), el autor hace referencia a tres grandes grupos de espacios, en donde cada uno de ellos presenta disímiles subclasificaciones. El primer grupo comprende aquellos espacios turísticos costeros y lacustres. En éstos el recurso agua y su distribución constituye el factor geográfico clave, en el que gran parte de las actividades de ocio y la dinámica de funcionamiento de la ciudad se da en torno a éste. En segundo lugar, hace referencia a aquellos espacios urbanos no costeros en los que, a diferencia del litoral, el turismo de sol y playa es desplazado por aquel de carácter histórico, cultural, religioso o el vinculado a la funcionalidad comercial de las urbes. Por último, destaca los espacios verdes, entre los que considera a aquellos agroturísticos y rururbanos, en este caso el espacio netamente rural y aquel que se desarrolla en el borde exterior del periurbano de las ciudades, constituye la base de las actividades turísticas y recreativas. Estas tres categorías forman parte de lo que el citado autor refiere como espacios turísticos polivalentes y abiertos, en los que existe una diversidad de actividades no turísticas que conviven con aquellos que sí lo son. Por otro lado, destaca espacios especializados, en los que el turismo se constituye como la actividad principal 0 , en algunos casos, la única. Si bien dentro de este grupo, pueden incluirse algunos de los mencionados en los de tipología polivalente, interesa resaltar a los enclaves termales, a aquellos que funcionan como centros invernales abocados al turismo de nieve y a los parques y reservas naturales. 
Tabla 1. Clasificación del espacio turístico.

\begin{tabular}{|c|c|c|c|}
\hline Lozato-Giotart (1990) & Boullón (2006b) & $\begin{array}{l}\text { Barrado y Calabuig } \\
\text { (2001) }\end{array}$ & Vera et al. (2011) \\
\hline $\begin{array}{l}\text { Polivalentes y abiertos: } \\
\text { 1) Costeros y lacustres } \\
\text { 2) Urbanos no costeros } \\
\text { 3) Verdes } \\
\text { Especializados más o } \\
\text { menos abiertos: } \\
\text { 1) Termales } \\
\text { 2) De nieve } \\
\text { 3) Parques y reservas } \\
\text { naturales }\end{array}$ & $\begin{array}{l}\text { 1) Espacio turístico } \\
\text { natural } \\
\text { 2) Espacio turístico } \\
\text { urbano }\end{array}$ & $\begin{array}{l}\text { 1) Turismo de } \\
\text { espacios litorales e } \\
\text { insulares } \\
\text { 2) Turismo en } \\
\text { espacios de montaña } \\
\text { y naturales } \\
\text { 3) Turismo urbano } \\
\text { 4) Turismo en } \\
\text { espacios rurales }\end{array}$ & $\begin{array}{l}\text { 1) Turismo en espacios } \\
\text { litorales } \\
\text { 2) Turismo en espacios } \\
\text { rurales } \\
\text { 3) Turismo en espacios } \\
\text { urbanos } \\
\text { 4) Turismo en espacios } \\
\text { de montaña } \\
\text { 5) Turismo en espacios } \\
\text { naturales protegidos } \\
\text { 6) Espacios } \\
\text { corporativos del turismo }\end{array}$ \\
\hline
\end{tabular}

Fuente: elaboración propia a partir de Lozato-Giotart (1990); Boullón (2006b); Barrado y Calabuig (2001); Vera et al. (2011).

Por su parte, Boullón (2006b), destaca sólo dos tipos de espacios turísticos, diferenciados por la intervención antrópica: el espacio natural y el espacio urbano. El citado autor establece que ambas tipologías espaciales "se mezclan en todas partes", dado que resulta difícil encontrar áreas sin intervención del hombre; sin embargo, resalta la presencia de ciertos espacios relicto en los que la actividad humana es nula o se manifiesta de manera reducida, que denomina como espacios naturales. En contrapartida a éstos, se destacan los espacios urbanos, con un carácter artificial, en el que el hombre lo ha intervenido de manera notoria, dando lugar a diferentes formas espaciales. Como establece Boullón, el espacio turístico se distribuye en estas dos categorías, a partir de la presencia de atractivos y elementos propios de la práctica de ocio. Cabe hacer mención, que el autor no desarrolla de forma específica el espacio rural, sino que se refiere al mismo como un espacio natural adaptado. Este espacio comprende

[...] las partes de la corteza terrestre donde predominan las especies del reino vegetal, animal y mineral, bajo las condiciones que le ha fijado el hombre. También, se le denomina espacio rural para señalar las tareas productivas que allí se realizan al arar y sembrar la tierra fértil, al construir canales de riego, al cortar los bosques originales, al plantar nuevos árboles, al criar ganado 0 al explotar yacimientos minerales. En el espacio natural adaptado (o rural) los árboles o los cereales crecen de acuerdo con las fuerzas de la naturaleza, pero es el hombre quien decide dónde deben nacer y cuánto tiempo van a vivir. (BOULLÓN, 2006b, p.64)

Asimismo, cuando el citado autor refiere al ambiente, destaca una clasificación del mismo en: naturaleza virgen y naturaleza adaptada, aludiendo en este último caso al ambiente rural, con intervención humana. Cabe destacar, que si bien esta concepción del espacio rural como parte del natural se encuentra arraigada en algunas líneas de trabajo, el mismo se configura como un espacio sumamente antropizado, de igual modo que el urbano. Si bien en este último se pueden identificar ciertas formas fijas resultantes de procesos productivos, que en comparación con el medio rural, son mucho más complejas, el espacio rural es sometido a otros cambios, que quiebran rotundamente con el funcionamiento del ecosistema natural, por lo tanto resulta de gran importancia diferenciarlos.

En última instancia, Vera et al. (2011) y Barrado y Calabuig (2001), no hablan especificamente de espacios turísticos, pero sí se refieren al desarrollo del turismo en disímiles espacios. En el caso de los primeros autores, a partir del establecimiento de entornos geográficos básicos: litoral e interior, especifican seis tipologías del espacio turístico: litoral, rural, de montaña, espacio natural protegido, corporativo y urbano (Vera et al., 2011). El turismo en el espacio litoral, es escenario de diversas prácticas y es el que mayores flujos turísticos representa, alcanzando cierto grado de consolidación, asociado principalmente al turismo de sol y playa; por su parte, el turismo en espacios urbanos, rurales y naturales ha reflejado un desarrollo notorio en el último tiempo; los espacios de montaña configuran sitios propicios para llevar a cabo diversas actividades recreativas y deportivas, encontrándose en la actualidad en una etapa de auge, aunque con ciertas limitantes vinculadas a los factores geográficos; en contrapartida, los espacios corporativos, funcionan como espacios construidos específicamente con el objetivo de captar visitantes 0 atender las necesidades y deseos vinculados al ocio. En este 
caso, las propuestas pueden ser diversas y asociadas a distintos fines: lúdicos, de consumo, entretenimiento, etc. (Vera et al., 2011).

En la obra de Barrado y Calabuig (2001) se distinguen, al igual que los autores citados anteriormente, cuatro tipologías de turismo que se desarrollan en distintos espacios. De la misma manera que Vera el al., refieren la existencia de un turismo en el espacio litoral, pero adicionando en su tratamiento a aquel de carácter insular. Se destacan aquí disímiles tipologías de estos espacios litorales, que dan lugar a otras, de acuerdo a determinadas variables en cuestión. En segundo lugar, refieren a un turismo en espacios de montaña y naturales. En este sentido, se nuclean las dos categorías disgregadas, propuestas por Vera et al. (2011). La diversidad de actividades en torno a éstos, tanto de carácter pasivo, como la contemplación del paisaje, hasta otras más extremas, como el turismo de nieve, caracterizan a esta tipología espacial. Por otra parte, el turismo urbano tiene como principal atractivo a las ciudades, con el cúmulo de componentes que las caracterizan. Entre estos factores se referencian: las actividades comerciales y recreativas que se desarrollan en las urbes, los servicios que en éstas se prestan y las funciones de transporte que cumplen, como nodos de conexión y distribución (Barrado y Calabuig, 2001). Por último, se destaca al turismo en el espacio rural, al igual que lo hacen Vera et al., como uno de los tipos de espacios más atractivos en los últimos años. Se establecen distintas características y actividades que son propias del medio rural, que pueden aprovecharse desde el punto de vista turístico y recreativo, y que contribuyen a la generación de ciertos impactos positivos en el territorio.

A partir de las clasificaciones establecidas, y teniendo como fin realizar un aporte a la disciplina, se presenta como propuesta una clasificación genérica del espacio turístico, que pueda aplicarse al análisis de distintas locaciones con cierta funcionalidad de ocio (Figura 5).

Figura 5. Propuesta de clasificación del espacio turístico

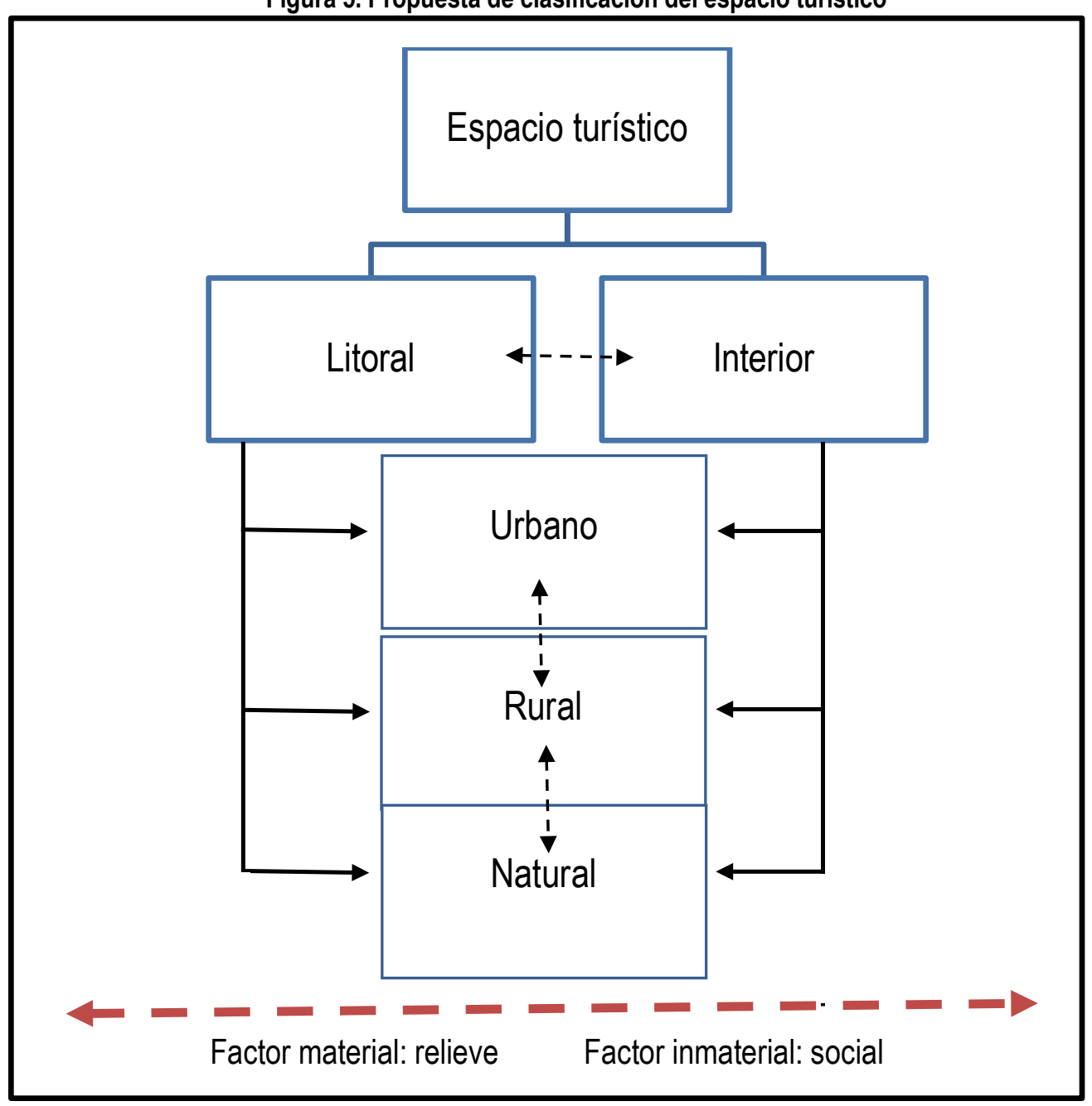

Fuente: elaboración propia a partir de Lozato-Giotart (1990); Boullón (2006b); Barrado y Calabuig (2001) y Vera et al. (2011). 
Para su establecimiento, se consideran los siguientes parámetros:

1) Variable de localización absoluta y dinámicas geográficas de funcionamiento: en este contexto, el espacio turístico es clasificado en litoral e interior.

2) Las variables: grado de antropización, recursos culturales y naturales, productos turísticos asociados, actividades socioeconómicas de la población y aquellas de tipo turístico recreativas realizadas por los visitantes, adicionado a la espacialidad de los individuos que habitan de forma permanente y temporaria dicho espacio, determinan una clasificación en: urbano, rural y natural.

3) Las variables: factor material relieve y factor inmaterial social, como elementos de relevancia geográfica, resultan transversales a la catalogación de los diferentes espacios turísticos anteriores.

Sobre la base de los criterios propuestos, puede decirse que el espacio turístico urbano comprende aquellas actividades de ocio que se enmarcan en el contexto dinámico de las ciudades. El consumo de bienes y servicios turísticos en el espacio urbano y sus inmediaciones y aquellos atractivos históricos, culturales y contemporáneos (construidos ad hoc), se trasforman en el escenario principal de la práctica de ocio. Los espacios corporativos que plantean Vera et al. (2011), pueden desarrollarse en este ámbito, constituyendo verdaderos enclaves y productos turísticos en sí mismos. Sin embargo, con una connotación diferente también podrán tener lugar en el ámbito rural.

El espacio turístico rural, se constituye como una categoría espacial con una dinámica territorial distinta al anterior. Si bien el espacio geográfico de base también se encuentra sumamente antropizado, el grado y forma de intervención humana se constituye de manera disímil al urbano. Las actividades, servicios y productos turísticos ofrecidos en el espacio rural, resultan diferentes, tanto en la escala de producción, en el volumen, como también en la demanda, siendo en estos casos más acotada y con un carácter más particularizado que en el espacio urbano. El agroturismo, el turismo de estancia, el enoturismo, entre otras modalidades, que en ciertas ocasiones no tienen que ver con la tradición rural (por ejemplo, reuniones laborales, congresos u otras actividades que se llevan a cabo en el entorno rural, pero que no albergan vínculo directo con el medio en el que se están desarrollando), se dan en este espacio, constituyendo alternativas turísticas y recreativas.

Por último, el espacio turístico natural, considera aquellas porciones de la superficie terrestre que no han sufrido alteración por parte del hombre, o que la misma ha sido reducida. El marco natural con escasa o nula intervención antrópica caracteriza el escenario en el que tienen lugar las prácticas de ocio. Al otorgarle carácter turístico al espacio natural, se le adjudica cierto grado de participación humana, por lo que aquellos sitios en los que la mano del hombre no ha actuado, quedan supeditados a recortes reducidos. En este sentido, este espacio turístico natural, contempla espacios con cierto grado de modificación, pero que siguen manteniendo la fisonomía natural del paisaje, al igual que el funcionamiento armónico de sus ecosistemas. Las modalidades del ecoturismo, turismo aventura, turismo patrimonial (por ejemplo, el vinculado a comunidades originarias que viven en relación con la naturaleza) y algunas prácticas deportivas, se estructuran como los principales productos que configuran parte de este espacio turístico.

Se debe tener en cuenta que cada una de estas tipologías espaciales, pueden desarrollarse en un entorno geográfico interior o litoral; y que a su vez, el relieve (entre otros factores geográficos), condiciona el desarrollo y dinámica de funcionamiento de los mismos, de igual manera que el factor social, configurado por el conjunto de representaciones sociales, imaginarios y espacios subjetivos que se generan en torno al espacio turístico y determinan una percepción particular y personal de acuerdo a cada visitante. Es así que un espacio turístico interior natural de montaña, tendrá una dinámica de funcionamiento distinta de aquel que se emplaza sobre una extensa llanura; o un espacio turístico litoral y rural, funcionará de forma distinta que un emprendimiento turístico agrario localizado en un territorio mediterráneo. Lo mismo sucederá con un espacio urbano de litoral, en el que la modalidad principal es la de sol y playa, a diferencia de aquel que se encuentra en un emplazamiento interior, y que el turismo cultural y de compras estructura parte de su oferta. Cabe destacar que si bien se establecen catalogaciones con funcionamientos y devenires característicos, entre cada uno de ellos existen relaciones que complejizan aún más el abordaje de dichos espacios.

\section{REFLEXIONES FINALES}

La presente investigación ha aportado en el sentido de comprender las múltiples acepciones del turismo y las relaciones en torno al espacio turístico y su clasificación, a partir de la establecida por diferentes autores clave.

Desde la perspectiva geográfica, el turismo es considerado como una práctica social y económica, que lleva aparejada la producción y consumo del 
espacio. Éste se transforma en el lugar clave en el que se dan los procesos de planificación y gestión turística de atractivos y productos y se inducen procesos de patrimonialización, tendientes a la valorización de ciertos recursos. Pero en este espacio, el funcionamiento del sistema turístico suele no darse siempre de manera armónica, dado que cada uno de los actores intervinientes, actúa con ciertos intereses y relaciones de poder.

En este sentido, el espacio turístico se trasforma en un espacio de disputa y conflicto, en el que la lucha entre el beneficio económico de los agentes privados, la preservación de los recursos, los impactos ambientales, la producción y consumo de bienes y servicios, los objetivos del Estado, el rol de la sociedad local, entre otras variables, deben ser articuladas a la hora de su planificación. Es por ello que la gestión de dicha actividad en los lugares de destino, se torna en una tarea sumamente compleja, dado que requiere compatibilizar diferentes objetivos buscados, de acuerdo a los distintos actores implicados.

Los diferentes autores analizados, si bien presentan distintas posiciones en relación a la conceptualización del espacio turístico, convergen en señalar que el mismo contiene una serie de particularidades que lo diferencian del resto de los espacios geográficos. Las prácticas turísticas que se manifiestan sobre el territorio han dado lugar a diversos intentos de clasificación en pos de buscar elementos que nos acerquen a comprender y a reflexionar la dinámica propia del turismo, y es en este el sentido que la investigación y los resultados que de ella se derivan pretenden contribuir.

En este contexto, se propone una clasificación que aspira a realizar una generalización en el marco de la diversidad de espacios turísticos existentes, con el fin de que se pueda aplicar al análisis de disímiles locaciones turísticas. Dicha catalogación, sentada sobre la base de autores clave de referencia en el ámbito de la geografía del turismo, constituye el punto de partida para una mayor profundización en la temática, que lleve a delinear caracteres más específicos, funcionalidades y dinámicas territoriales, producto del devenir de cada uno de estos espacios.

Como se ha establecido, las tipologías propuestas no deben verse como compartimentos estancos y separados unos de otros, sino en constante relación. Las dinámicas territoriales no sólo se producen en la dimensión material del espacio, sino también en la esfera simbólica, donde las percepciones, representaciones, imaginarios y apreciaciones del medio, se traducen en valorizaciones y dinámicas de funcionamiento y consumo espacial que vuelven a generar y reproducir nuevas lógicas, a partir de las experiencias vividas en el espacio turístico.

\section{BIBLIOGRAFÍA}

ACEBO IBÁÑEZ, E.; SCHLÜTER, R. Diccionario de turismo, Buenos Aires, Claridad, 2012.

ALMIRÓN, A. Turismo y espacio. Aportes para otra geografía del turismo. GEOUSP - Espacio y Tiempo, n. 16, p. 166-180, 2004.

ALMIRÓN, A; BERTONCELLO, R.; TRONCOSO, C. Turismo, patrimonio y territorio. Una discusión de sus relaciones a partir de casos de Argentina. Estudios y Perspectivas en Turismo, v. 15, p. 101-124, 2006.

ANTÓN CLAVÉ, S.; FERNÁNDEZ TABALES, A.; GONZÁLEZ REVERTÉ, F. Los lugares turísticos. In: Antón Clavé, S.; González Reverté, F. "A propósito del turismo. La construcción social del espacio turístico". Barcelona, UOC, 2007.

BALASTRERI RODRIGUES, A. Turismo e territorialidades plurais- lógicas excludentes ou solidariedade organizacional. In: Geraiges de Lemos, A.; Arroyo, M.; Silveira, L. "América Latina: cidade, campo e turismo". San Pablo: CLACSO, Consejo Latinoamericano de Ciencias Sociales, 2006.

BARRADO, D.; CALABUIG, J. (Ed.). Geografía Mundial del Turismo, Madrid, Síntesis, 2001.

BARRETTO, M. Turismo, patrimonio cultural de la sociedad. II Congreso Internacional de Turismo Cultural NAyA, $2003 . \quad$ Recuperado de: http://equiponaya.com.ar/turismo/congreso2003/ponen cias/Margarita_Barretto.htm\#_tn1 Consulta: 03/04/2017.

BARRETTO, M; OTAMENDI, A. Introducción. In: Barretto, M. (Coord.). "Turismo, reflexividad y procesos de hibridación cultural en América del Sur austral", El Sauzal (Tenerife), ACA y PASOS, 2010.

BERTONCELLO, R. (Comp.) Turismo y geografia: lugares y patrimonio natural-cultural de la Argentina, Buenos Aires, CICCUS, 2008.

BERTONCELLO, R. Turismo y patrimonio, entre la cultura y el negocio. In: Duarte, M.; Ramos, M. (Orgs.). "Geografia, turismo e patrimonio cultural", San Pablo, Annablume, 2010.

BERTONCELLO, R. Turismo y territorio. Otras prácticas, otras miradas. Aportes y Transferencias, v. 2, n. 6, p. 29-50, 2002.

BOULLÓN, R. Espacio turístico y desarrollo sustentable. Aportes y Transferencias, v. 2, n. 10, p. 17-24, 2006a.

BOULLÓN, R. Planificación del espacio turístico (4ta. Ed.), México, Trillas, 2006b.

BRIDA, G.; LANZILOTTA, B.; PEREYRA, J.; PIZZOLON, F. El turismo como factor del crecimiento económico: un estudio comparativo de los países del MERCOSUR. Revista de Economía Mundial, n. 34, p. 75-96, 2013.

BRIDA, G.; PEREYRA, J.; PULINA, M.; SUCH, M. Causalidad entre turismo y crecimiento económico de largo plazo: una revisión crítica de la literatura econométrica. Innovar Journal, v. 47, n. 23, p. 53-64, 2013.

CALLIZO SONEIRO, J. El espacio turístico de Chadefaud, un entrevero teórico: del historicismo al materialismo 
dialéctico y el sistemismo Behaviourista. Geographicalia, v. 26, p. 37-44, 1989.

CAMMARATA, E. El turismo como práctica social y su papel en la apropiación y consolidación del território. In: GERAIGES DE LEMOS, A.; ARROYO, M.; SILVEIRA, L. "América Latina: cidade, campo e turismo". San Pablo, CLACSO, 2006.

COHEN, C.; BENSENY, G. Turismo y territorio. Un abordaje teórico desde los conceptos: Recursos Territoriales y Atractivos Turísticos. In: LAN, D. (Comp.). "Geografías en diálogo: aportes para la reflexión", Tandil, Universidad Nacional del Centro de la Provincia de Buenos Aires, 2016.

COLES, T.; DUVAL, D.; HALL, M. Sobre el turismo y la movilidad en tiempos de movimiento y conjetura posdisciplinar. Política y sociedad, v. 42, n. 2, p. 181198, 2005.

COOPER, C. Una introducción al turismo. In: COOPER, C. et al. "El turismo: teoría y práctica". España, Síntesis, 2007.

CROSBY, A.; MOREDA, A. Elementos básicos para un turismo sostenible en áreas naturales, Madrid, Centro Europeo de Formación Ambiental y Turística, 1996.

DA SOLLER, J.; CASTROGIOVANNI, A. Geografia e turismo: caminhos e desafios para a complexa leitura do patrimônio de Garopaba (SC). Revista Brasileira de Ecoturismo, v. 7, n. 1, p. 198-214, 2014.

DE PAULA, S. Controle do espaço urbano e o território como produto turístico: reflexão teórica sobre a segregação imposta da população em situação de rua no contexto de megaeventos (Río 2016). Anais Brasileiros de Estudos Turísticos - ABET. Juiz de Fora, v. 6, n. 3, p. 21-29, 2016.

ERCOLANI, P.; BENSENY, G. Aportes metodológicos para la configuración de espacio turístico a través de la dimensión espacio-temporal. Aportes y Transferencias, v. 14, n.1, 59-80, 2010.

FIGUEROLA PALOMO, M. La economía del turismo, Madrid, Alianza, 1985.

GARCÍA, R. Espaço e Turismo: Reflexões Contemporâneas. Anais Brasileiros de Estudos Turísticos - ABET. Juiz de Fora, v. 3, n. 2, p. $41-42,2013$.

GETINO, O. Turismo y desarrollo en América Latina, México, Limusa, 1987.

GETINO, O. Turismo. Entre el ocio y el neg-ocio. Identidad cultural y desarrollo para América Latina y el Mercosur, Buenos Aires, CICCUS-La Crujía, 2003.

GIBSON, C. Geographies of tourism: internationalizing geography?. Progress in Human Geography, v. 32, n. 3, p. 1-16, 2008.

GUIMARÃES, V. Encontros turísticos: refl exões sobre o turismo através da subjetividade do turista. Anais Brasileiros de Estudos Turísticos - ABET. Juiz de Fora, v. 2, n. 1, p. 55-64, 2012.

GOELDNER, C.; RITCHIE, J. Tourism: Principles, practices, philosophies (9na. Ed), New Jersey, Wiley, 2002.

GUZMÁN VILAR, L.; GARCÍA VIDAL, G. Fundamentos teóricos para gestión turística del patrimonio cultural desde la perspectiva de la autenticidad, Málaga, EUMED, 2010.
HALL, M. Framing tourism geography: notes from the underground. Annals of Tourism Research, v. 43, p. 601-623, 2013.

HALL, M.; PAGE, S. The Geography of Tourism and Recreation: Environment, Place and Space, New York, Routledge, 2014.

HERNÁNDEZ ESPINOSA, R.; MONTERRUBIO, C. Construcciones sociales del espacio turístico recreativo. Un estudio interpretativo sobre las prácticas recreativas en el Parque Nacional Molino de Flores Nezahualcóyotl, México. Turismo y Sociedad, v. XIX, p. 37-48, 2016.

HIERNAUX, D. ¿Cómo definir el turismo? Un repaso disciplinario. Aportes y Transferencias, v. 6, n. 2, p. 1127, 2002.

HIERNAUX, D. El giro cultural y las nuevas interpretaciones geográficas del turismo. GEOUSP - Espacio y Tiempo, n. 23, p. 177-187, 2008.

HIERNAUX, D. Geografía del turismo. In: LINDÓN, A.; HIERNAUX, D. (Dirs.). "Tratado de Geografía Humana". México, Antrhopos, 2006.

KNAFOU, R. Turismo e territorio. Para uma abordagem científica do turismo. In: BALASTRERI RODRIGUES, A. (Org.). "Turismo e Geografia. Reflexões teóricas e enfoques regionais". San Pablo, Hucitec, 1996.

KNAFOU, R.; STOCK, M. Tourisme. In: LEVY, J.; LOUSSAULT, M. "Dictionnaire de la géographie et de l'espace des sociétés". París, Belin, 2003.

KUPER, D.; BERTONCELLO, R. Turismo e infraestructura urbana: la refuncionalización de la estación del ferrocarril de Gualeguaychú como atractivo turístico. Boletín Geográfico, v. 31, p. 471-488, 2008.

LEFEBVRE, H. La producción del espacio. Madrid, Capitán Swing Libros, 2013.

LEIPER, N. The framework of tourism. Annals of Tourism Research, v. 4, n. 6, p. 390-407, 1979.

LOZATO-GIOTART, J. Geografía del turismo. Del espacio contemplado al espacio consumido, Barcelona, Masson, 1990.

MANTERO, J. Turismo: la opción incluyente. Aportes y Transferencias, v. 2, n. 1, p. 119-136, 1997.

MONTERRUBIO, J.; COLÍN, R. La inexistencia del derecho turístico: Un análisis conceptual. Estudios $y$ perspectivas en turismo, v. 6, n. 18, p. 727-740, 2009.

MORERA, C.; MIRANDA, P. De la geografía del turismo al análisis territorial del turismo: el rastro en Costa Rica. Revista Geográfica de América Central, n. 54, p. 15-43, 2015.

OMT (ORGANIZACIÓN MUNDIAL DEL TURISMO). Entender el turismo: Glosario Básico, 2008. Recuperado de: $<$ http://media.unwto.org/es/content/entender-el-turismoglosario-basico>. Consulta: 29/11/2015.

ONU; OMT (ORGANIZACIÓN DE LAS NACIONES UNIDAS; ORGANIZACIÓN MUNDIAL DEL TURISMO). Recommendation on tourism statistics, ONU, Nueva York (Estados Unidos), 1994.

ONU; OMT (ORGANIZACIÓN DE LAS NACIONES UNIDAS; ORGANIZACIÓN MUNDIAL DEL TURISMO). Recomendaciones internacionales para estadísticas de turismo, ONU, Madrid-Nueva York, 2000. 
PANOSSO NETTO, A. Filosofía del turismo: una propuesta epistemológica. Estudios y perspectivas en turismo, v. 4, n. 16, p. 389-402, 2007.

PINASSI, A. ERCOLANI, P. Geografía del turismo: análisis de las publicaciones científicas en revistas turísticas. El caso de Argentina. Cuadernos de geografía: revista colombiana de geografía, v.24, n.1, p. 213-230, 2015.

PINASSI, A. Espacio vivido: análisis del concepto y vínculo con la geografía del turismo. Geographos, v. 6, n. 78, p. 135-150, 2015.

PINASSI, A. La configuración de un nuevo espacio turístico recreativo a través de la valorización del patrimonio cultural: el caso de Bahía Blanca. Tesis de Doctorado en Geografía, Universidad Nacional del Sur, 2016.

PINASSI, A. Los adolescentes de la ciudad de Bahía Blanca (Rep. Argentina) y el vínculo con el patrimonio cultural: ¿Es posible hablar de un espacio vivido patrimonial? Lurralde: investigación y espacio, v.41, p. 55-91, 2017.

PINASSI, A.; ERCOLANI, P. Turismo cultural en el centro histórico de Bahía Blanca. Análisis y propuestas para su desarrollo turístico- recreativo. Anuario de Turismo y Sociedad, v.13, p. 145-169, 2012.

PINASSI, A.; VAN HOOF, B.; ERCOLANI, P. Perceptions about cultural heritage and recreational sites among older adults in Bahia Blanca, Argentina. Journal of Cultural Heritage Management and Sustainable Development, v.7, n.1, p. 72-90, 2017.

POCIDONIO, E.; SILVA, T. Geografías y turismo. Espaço Aberto, v. 5, n.2, p. 31-48, 2014.

PRATS, L. Antropología y patrimonio, Barcelona, Ariel, 1997.

PRATS, L. El concepto de patrimonio cultural. Politica y Sociedad, n. 27, p. 63-76, 1998.

RAE (REAL ACADEMIA ESPAÑOLA). Recuperado de: <http://www.rae.es/>. Consulta: 28/01/2017.

RAMOS LIZANA, M. El turismo cultural, los museos y su planificación, España, Trea, 2007.

RUSSO, A. Las nuevas fronteras del estudio del turismo: retos conceptuales y epistemológicos. Revista CIDOB d'Afers Internacionals, n. 113, p. 15-32, 2016.

SALINAS CHÁVEZ, E.; MEDINA PÉREZ, N. Los productos turísticos, pilares de la comercialización. Dos ejemplos del centro histórico de la Habana, Cuba. Estudios y Perspectivas en Turismo, v. 18, n. 2, 2009.

SANCHO, A. Introducción al turismo, Madrid, OMT (Organización Mundial del Turismo), 1998.

SANTANA TALAVERA, A. Antropología y turismo ¿Nuevas hordas, viejas culturas?, Barcelona, Ariel, 1997.

SILEO, S. Geografía, espacio y turismo, Buenos Aires, Universidad Nacional de Quilmes, 2014.

SOJA, E. Thirdspace. Journeys to Los Angeles and Other real-and-Imagined Places. Cambridge, Blackwell, 1996.
SOJA, E. Postmetrópolis. Estudios críticos sobre las ciudades y las regiones. Trad. Hendel y Cifuentes. Madrid, Traficantes de Sueños, 2008.

SUNYER, N.; GALACHO JINÉNEZ, B.; GARCÍA HERNÁNDEZ, M.; LÓPEZ OLIVARES, D. Técnicas e instrumentos para el análisis territorial. In: ANTÓN CLAVÉ, S.; GONZALEZ REVERTÉ, F. (Coords.). "Planificación territorial del turismo". Barcelona, UOC, 2005.

TAVARES, J.; NEVES, O.; VIEIRA JUNIOR, J. La atractividad turística de Belo Horizonte según la percepción de sus habitantes. Estudios $y$ Perspectivas en Turismo, v. 19, n. 6, p. 1072-1089, 2010.

TORREJÓN, A. Tesauro turístico argentino, Buenos Aires, MINTUR, 2013.

TOSELLI, C. Algunas reflexiones sobre el turismo cultural. Pasos, Revista de Turismo y Patrimonio Cultural, v. 4, n. 2, p. 175-182, 2006.

TRESSERRAS, J. El color del turismo cultural y creativo. Revista Santiago creativo, v. 1, p. 51-53, 2014.

TRESSERRAS, J. Gestión pública privada del turismo cultural y el desarrollo comunitario. VIII Congreso Nacional de Turismo - II Congreso Internacional de Investigación Turística, Monterrey (México), 2006.

TRONCOSO, C. Creando un lugar turístico y patrimonial: las transformaciones de la Quebrada de Humahuaca a partir de los procesos de construcción de atractividad turística y patrimonialización. Tesis de Doctorado en Geografía, Universidad de Buenos Aires, Buenos Aires (Argentina), 2008.

TRONCOSO, C. La actualidad de los estudios sobre el turismo. Temas, perspectivas y contribuciones desde las ciencias sociales. Ítems del CIEP Revista de Ciencia Sociales y Humanas, n. 1, p. 63-80, 2016.

TRONCOSO, C. Turismo y patrimonio en la Quebrada de Humahuaca. Lugar, actores y conflictos en la definición de un destino turístico argentino. Tenerife, Pasos Edita, 2012.

URRY, J. La mirada del turista, Lima, Universidad de San Martín de Porres, 2004.

VALLS, J. Las claves del mercado turístico. Bilbao, Deusto Turismo, 1996.

VELASCO GONZÁLEZ, M. Conceptos en evolución: turismo, cultura y turismo cultural. In: Pulido, J. (Coord.); De La Calle, M.; Velasco González, M. "Turismo cultural", España, Síntesis, 2013.

VERA REBOLLO, F. (Coord.); LÓPEZ PALOMEQUE, F.; MARCHENA, M.; ANTÓN CLAVÉ, S. Análisis territorial del turismo y planificación territorial del turismo, Valencia, Tirant lo Blanch, 2011. 